UNITED STATES DEPARTMENT OF THE INTERIOR

GEOLOGICAL SURVEY

\title{
MINERALOGICAL AND CHEMICAL COMPOSITION OF SAMPLES FROM THE CHRISTY VANADIUM-TITANIUM DEPOSIT, HOT SPRING COUNTY, ARKANSAS
}

By

G. N. Breit ${ }^{1}$, C. Rice ${ }^{1}$, D.L. Fey ${ }^{2}$, and W.J. Sadler ${ }^{2}$

Open-File Report 92-288

This report is preliminary and has not been reviewed for conformity with U.S. Geological Survey editorial standards and stratigraphic nomenclature. Use of trade names is for descriptive purposes only and does not imply endorsement by the U.S. Geological Survey

1 U.S. Geological Survey, Branch of Sedimentary Processes, Box 25046 MS 916 Denver Federal Center, Denver, Colorado 80225.

2 U.S. Geological Survey, Branch of Geochemistry, Box 25046

MS 973 Denver Federal Center, Denver, Colorado 80225. 


\section{CONTENTS}

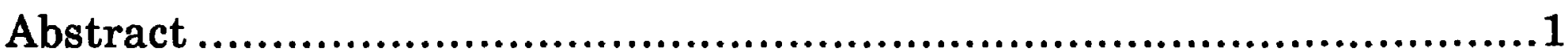

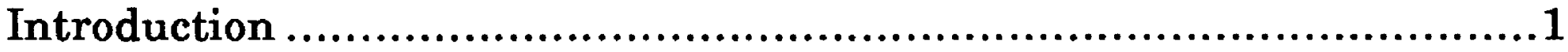

Geologic Setting ......................................................2

Sampling ...................................................................4

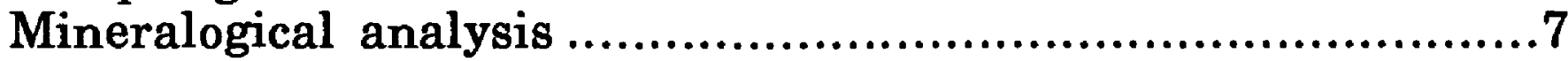

Chemical analyses ......................................................9

Whole-rock analyses...........................................9

Partial dissolution analyses..................................9

Statistical Analysis..................................................... 13

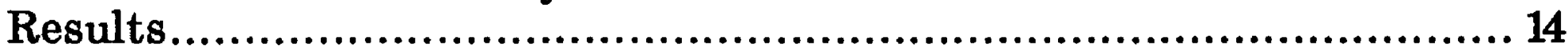

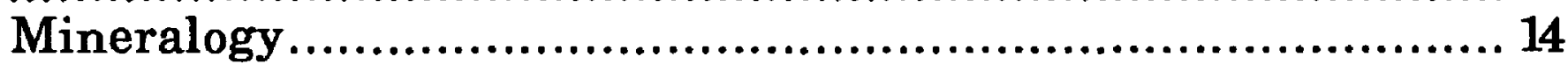

Chemical Composition................................................... 16

Whole-rock .................................................. 16

Partial dissolution............................................ 21

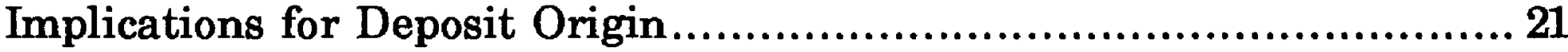

Acknowledgments......................................................... 24

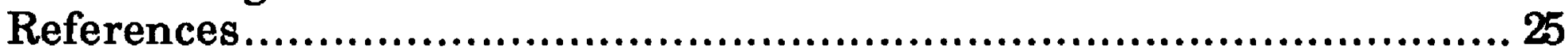

\section{FIGURES}

1. Generalized physical map of the Christy mine, $1985 \ldots \ldots \ldots \ldots \ldots \ldots \ldots \ldots$

2. Generalized geologic map of the Christy mine, $1991 . \ldots \ldots \ldots \ldots \ldots \ldots \ldots \ldots 6$

3. X-ray diffractogram of $<2 \mu \mathrm{m}$ separate from sample $85-024 . \ldots \ldots \ldots \ldots \ldots . .8$

4. Reagents and conditions used for partial dissolution analyses..........11

5. Box plots of element abundances. ...................................... 17

\section{TABLES}

1. Paleozoic sedimentary rocks in the Christy deposit............................3

2. X-ray diffraction reflection positions used estimate mineral abundances ....................................................................7

3. Summary statistics of whole-rock element abundances. ................. 10

4. Results of the partial extraction analyses.............................. 12

5. Correlation matrix for whole-rock element abundances.................. 22

\section{APPENDICES}

Appendix 1. Sample descriptions.............................................28 Appendix 2. Sample Mineralogy as determined by x-ray diffraction...... 34 Appendix 3. Whole-rock chemical compositions............................ 36 


\title{
MINERALOGICAL AND CHEMICAL COMPOSITION OF SAMPLES FROM THE CHRISTY VANADIUM-TITANIUM DEPOSIT, HOT SPRING COUNTY, ARKANSAS
}

by

\author{
G. N. Breit, C. Rice, D.L. Fey, and W.J. Sadler
}

\begin{abstract}
The Christy vanadium-titanium deposit is hosted by highly fractured and altered Paleozoic sedimentary rocks near the contact with the Cretaceous Magnet Cove intrusive complex. Major minerals in the deposit include quartz, kaolinite, smectite and goethite. Minor phases include brookite, anatase, adularia, illite/mica(?), manganese oxides, and pyrite. The deposit is a product of contact metamorphism, hydrothermal solutions, and weathering. Chemical analyses determined that barium, strontium, rare earth elements, niobium, titanium and vanadium are enriched in the deposit relative to the barren country rock. This suite of elements is consistent with enrichments identified by Erickson and Blade (1963) of sedimentary rocks altered by the intrusion of the Magnet Cove complex. Partial dissolution techniques along with the energy dispersive spectrometer on a scanning electron microscope determined that most vanadium in the deposit is contained in clay minerals and goethite.
\end{abstract}

\section{INTRODUCTION}

Unusual vanadium deposits occur along the contacts of alkaline intrusive igneous complexes and Paleozoic sedimentary rocks in Garland and Hot Spring Counties, Arkansas (Hollingsworth, 1967; Howard, 1974; Flohr, 1991; Willis and others, $1990 ; 1991$ ). These deposits are unique in that no deposits containing similarly large amounts of vanadium have been described near other alkaline intrusions. To better understand the origin of these deposits, a geochemical and mineralogical investigation of the Christy vanadium-titanium (V-Ti) deposit was conducted. Greater understanding of the deposit will lead to more reliable vanadium resource estimates and identification of criteria for the recognition of areas favorable for similar deposits.

The Christy V-Ti deposit is located in SW1/4, SW1/4 of Sec.16, T.3S., R.17W., Hot Spring County, Arkansas. The deposit was first described by Williams (1891) largely because of the large abundance of brookite. Subsequent geologic and mineral recovery studies focused on the titanium potential of the deposit (Holbrook, 1947; Reed, 1949; Fryklund and Holbrook, 1950; Toewe and others, 1968). No significant amounts of titanium have been produced from the Christy deposit, although other deposits within and near the Magnet Cove intrusive complex have produced approximately 5000 tons of rutile concentrates (Toewe and others, 1968). Steele and Wagner (1976) estimated that 120,000 tons of $\mathrm{TiO}_{2}$ concentrates of 91.7 percent purity were contained in the Christy deposit. The lack of development of the property for titanium production is partly due to the high niobium content of the brookite $(0.2$ to $2 \mathrm{wt} . \% \mathrm{Nb}$ (Flohr, 1991)), which is difficult to remove and interferes with end uses of the titanium. 
Although titanium has not been produced from the Christy deposit, vanadium ore has been intermittently mined since 1984 and was last produced in 1989. Reed (1949) first reported that some portions of the Christy deposit contained greater than 1 weight percent $\mathrm{V}_{2} \mathrm{O}_{5}$. Steele and Wagner (1976) estimated vanadium reserves in the Christy deposit at nearly 2 million tons with an average grade of 1 weight percent $\mathrm{V}_{2} \mathrm{O}_{5}$. Ore mined from the Christy deposit had an estimated grade of 0.7 weight percent $\mathrm{V}_{2} \mathrm{O}_{5}$ (D.R. Owens, 1989, personal communication to J.M. Howard, Arkansas Geological Commission).

The composition of ore and altered rocks adjacent to the Christy deposit have been generally described by Fryklund and Holbrook (1950). They noted that the brookite ore has been extensively oxidized and contains abundant clay minerals. As a result of their observations, they proposed that the V-Ti deposit formed simultaneous with recrystallization of siliceous host rocks and was related to emplacement of nearby igneous rocks.

This report presents additional information on the vanadium ore in the Christy deposit. Descriptions of samples collected from the open-pit mine along with their chemical and mineralogical compositions are listed. Preliminary interpretations of these data are consistent with interpretations of Flohr (1991), and Willis (1992).

\section{Geologic Setting}

Maps of the area of the Christy deposit are presented by Danilchik and Haley (1964) and Fryklund and Holbrook (1950). The Christy deposit is located within about 200 feet of the contact of Paleozoic sedimentary rocks with the Cretaceous Magnet Cove intrusive complex (Fryklund and Holbrook, 1950). Exposed igneous rocks of the Magnet Cove complex were intruded $100 \mathrm{Ma}$ (Zartman, 1977) as part of a subvolcanic emplacement (Erickson and Blade, 1963). Descriptions of the igneous rocks in the complex are presented in Erickson and Blade (1963) and Flohr and Ross (1989; 1990). The Magnet Cove intrusive complex is roughly elliptical and covers 4.6 square miles. The core of the complex contains carbonatite and ijolite, and is surrounded by rings of trachyte, phonolite, and syenite. Jacupirangite was emplaced in late piercing intrusions. Exposed igneous rocks nearest the deposit are mapped as garnet-psuedoleucite syenite (Erickson and Blade, 1963).

Paleozoic rocks that contact the intrusive near the deposit include the Silurian Blaylock Sandstone and Missouri Mountain Shale, Devonian and Mississippian Arkansas Novaculite and the Mississippian Stanley Shale (table 1; Danilchik and Haley, 1964). Although alteration and structural displacement within the deposit make identification of the original rock units difficult, most of the Christy deposit is hosted by the middle and lower divisions of the Arkansas Novaculite. On the south, the deposit is bounded by the Missouri Mountain Shale (Fryklund and Holbrook, 1950; Willis, 1992). 
Table 1. Description of Paleozoic sedimentary rocks near the Christy V-Ti deposit. Modified from Danilchik and Haley (1964).

Formation

MISSISSIPPIAN

Stanley Shale
Description

Medium dark-gray, platy shale that contains thick beds of medium dark-gray to olive-gray fine-grained sandstone.

Estimated maximum thickness 6000 feet.

\section{DEVONIAN AND MISSISSIPPIAN}

Arkansas Novaculite

\section{SILURIAN}

\author{
Missouri Mountain \\ Shale
}

Blaylock Sandstone
Upper unit of thin to medium bedded novaculite and sandstone; middle unit of thin bedded novaculite interbedded with thin beds of dark gray fissile shale; lower unit is massive novaculite; total thickness approximately 600 feet.
Pale red, thin-bedded shale.

Total thickness 100 to 120 feet.

Sandstones and siltstone interbedded with thin beds of shale. Thickness near 200 feet.

The Christy deposit is on the north limb of an overturned and faulted anticline that plunges to the southwest where it is truncated by the Magnet Cove intrusive complex. This fold is one of a series of northeast trending flexures that formed during the late Paleozoic Ouachita Orogeny and now define the Zig Zag Mountains. As part of the folding, brittle units like the Arkansas Novaculite were fractured. The fracturing of these rocks favored the later passage of hydrothermal fluids that evolved from the Magnet Cove intrusive complex. Igneous dikes emplaced as part of the Magnet Cove intrusions cross-cut the deposit as smooth-sided, steeply dipping zones as wide as 3 meters. The offset of some dikes along fractures indicates some displacement post-dated intrusion of the dikes. Because the Magnet Cove complex formed by multiple intrusive events, this displacement is considered coeval with intrusion of later components of the alkaline complex.

During the early Tertiary extensive weathering produced bauxite deposits on Cretaceous nepheline syenite intrusions approximately 30 miles from the Christy deposit (Gordon and others, 1959). Similar intense weathering probably impacted the mineralogy of the Christy deposit. Increased permeability caused 
by the extensive fracturing enhanced the passage of water from the surface downward through the deposit. The percolation of water resulted in extensive clay alteration of some lithologies. The supergene alteration of the deposit probably continues at present because of the humid climate of Arkansas. Arkansas has hot summers, cool winters and precipitation averages about 54 inches per year. Saprolite extends to depths of approximately 5 feet over most of the igneous rocks in the Magnet Cove complex (Hoelscher, 1987).

\section{METHODS \\ Sampling}

Samples were collected in 1985 and 1990 from the Christy open-pit vanadium mine. From 1985 to 1990 the working level moved down forty feet from the 520 to the 480 working level. A generalized map of the mine as it appeared in December 1985 along with sample locations of the 1985 sample set are presented on figure 1. Figure 2 is a generalized geologic map modified from Willis (1992) that contains the location of most of the samples collected in 1990.

Most samples were collected from walls between working levels. Because of the heterogeneity of rocks within the deposit, chip samples were collected to obtain representative material. The samples were collected to be representative of rocks typical of the deposit and include samples from within and outside the defined ore body (fig. 1; fig. 2). Sample descriptions are presented in appendix 1.

Based on the composition and appearance of the samples, they were classified as recrystallized novaculite, hornfels, argillized hornfels, massive claystone, argillized igneous dike, vuggy quartz, and gossan. Recrystallized novaculite is gray to white and physically resembles a fine-grained quartzite. Hornfels samples are competent and very fine-grained with alternating white and gray siliceous layers that probably formed by recrystallization of the middle unit of the Arkansas Novaculite and other Paleozoic shales. Argillized hornfels are earthy and clay-rich rocks that are layered much like the hornfels. Samples composed of massive hard green to gray clay were classified as claystones. These samples are typically more competent than other argillized samples and lack the distinctive layering of the hornfels. The argillized igneous dike samples are soft and earthy due to the abundance of clay and typically have small scale color variations that resemble a porphyritic rock. Vuggy quartz samples are mainly a porous aggregate of smoky and clear quartz crystals that contain variable amounts of interstitial clay. Gossans are composed of quartz thickly coated with iron oxides, intermixed clay and iron oxides, or massive iron oxides. They range from hard and siliceous to earthy and clay-rich. 


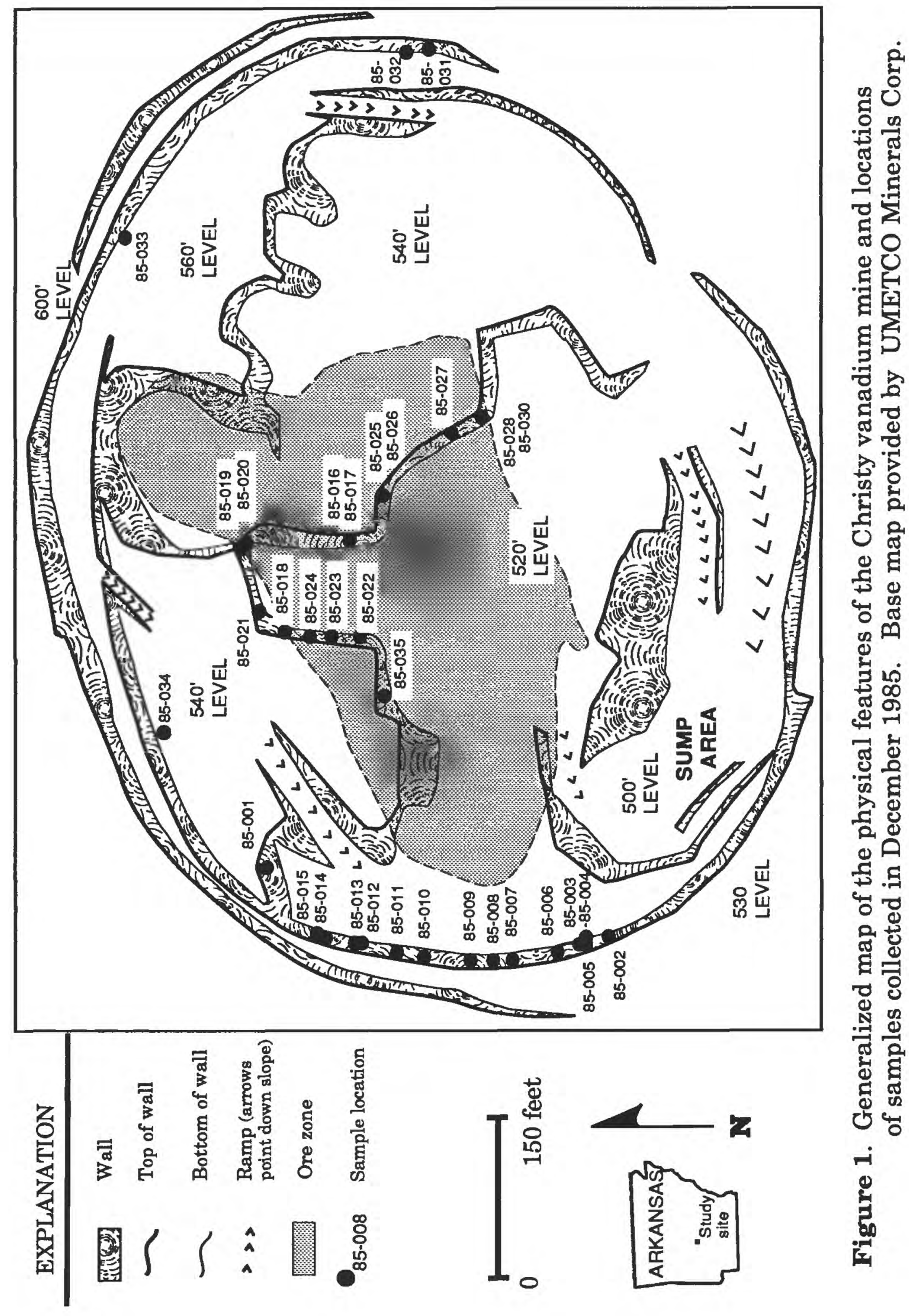




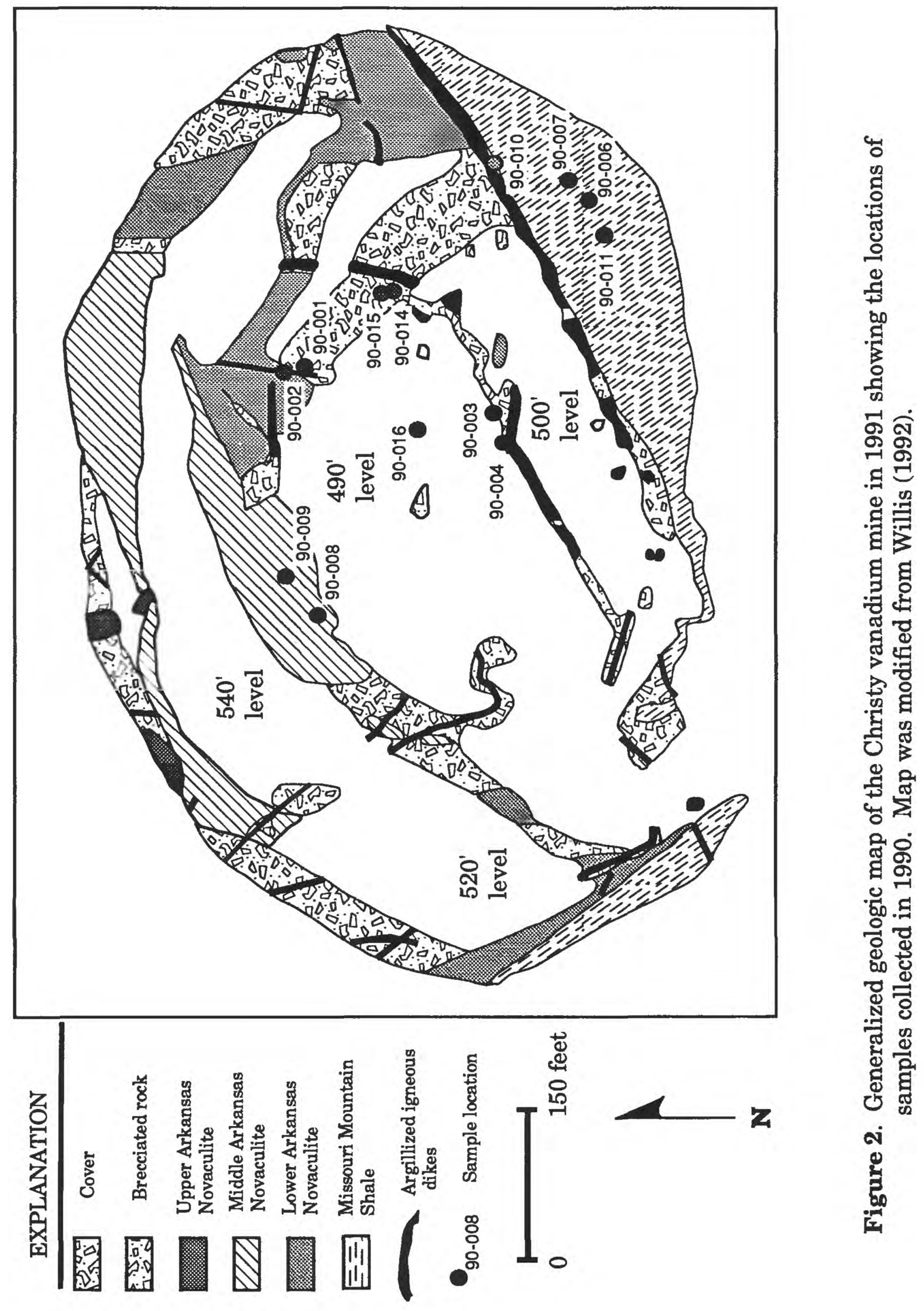


Mineralogical Analysis

Whole-rock X-ray diffraction (XRD) was used to estimate the relative abundance of common mineral constituents of the samples. The analyses were performed on packed-powder mounts that were scanned at $1^{\circ} 2 \theta /$ minute using nickel-filtered $\mathrm{Cu}-\mathrm{K}_{\alpha}$ radiation and a graphite monochromater. The relative abundance of the minerals among the samples was estimated from peak heights or areas (table 2). The abundance estimates are approximate because of the large range of mineral compositions and their associated matrix affects. Results of XRD are summarized in appendix 2. Additional mineralogical information was obtained using standard petrographic techniques on polished thin sections and by use of a scanning electron microscope (SEM) equipped with a energy dispersive spectrometer (EDS).

The clay-sized fraction (less than two micrometers $(\mu \mathrm{m})$ ) of sample 85-024 was prepared to evaluate the clay mineralogy of a vanadium-rich claystone sample. This separate was prepared using a high speed centrifuge and techniques of Jackson (1969). The clay separate was saturated with sodium and an oriented mount prepared according to the technique of Drever (1973). The mount was X-rayed after it was air dried and after treatment with ethylene glycol (fig. 3).

Table 2. X-ray diffraction reflections used to estimate the relative abundance of major minerals in samples from the Christy deposit. Peak positions based on $\mathrm{Cu} \mathrm{K}_{\alpha}$ radiation (wavelength equal to 1.540 angstroms)

\begin{tabular}{|c|c|c|c|}
\hline Mineral & $\begin{array}{l}\text { Miller } \\
\text { Indices }\end{array}$ & $\begin{array}{c}\text { d-spacing } \\
(\AA)\end{array}$ & 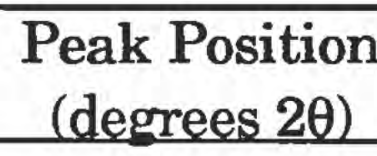 \\
\hline Adularia & (220) & 3.31 & $26.9^{\circ}$ \\
\hline Anatase & (101) & 3.52 & $25.3^{\circ}$ \\
\hline Brookite & $(120 ; 111)$ & $3.51 ; 3.47$ & $25.4^{\circ} ; 25.7^{\circ}$ \\
\hline Goethite & (110) & 4.18 & $21.2^{\circ}$ \\
\hline Kaolinite & (001) & 7.17 & $12.3^{\circ}$ \\
\hline Illite/Mica & (001) & 10.0 & $8.8^{\circ}$ \\
\hline Smectite & (001) & 13.9 & $6.4^{\circ}$ \\
\hline Quartz & (100) & 4.26 & $20.8^{\circ}$ \\
\hline
\end{tabular}



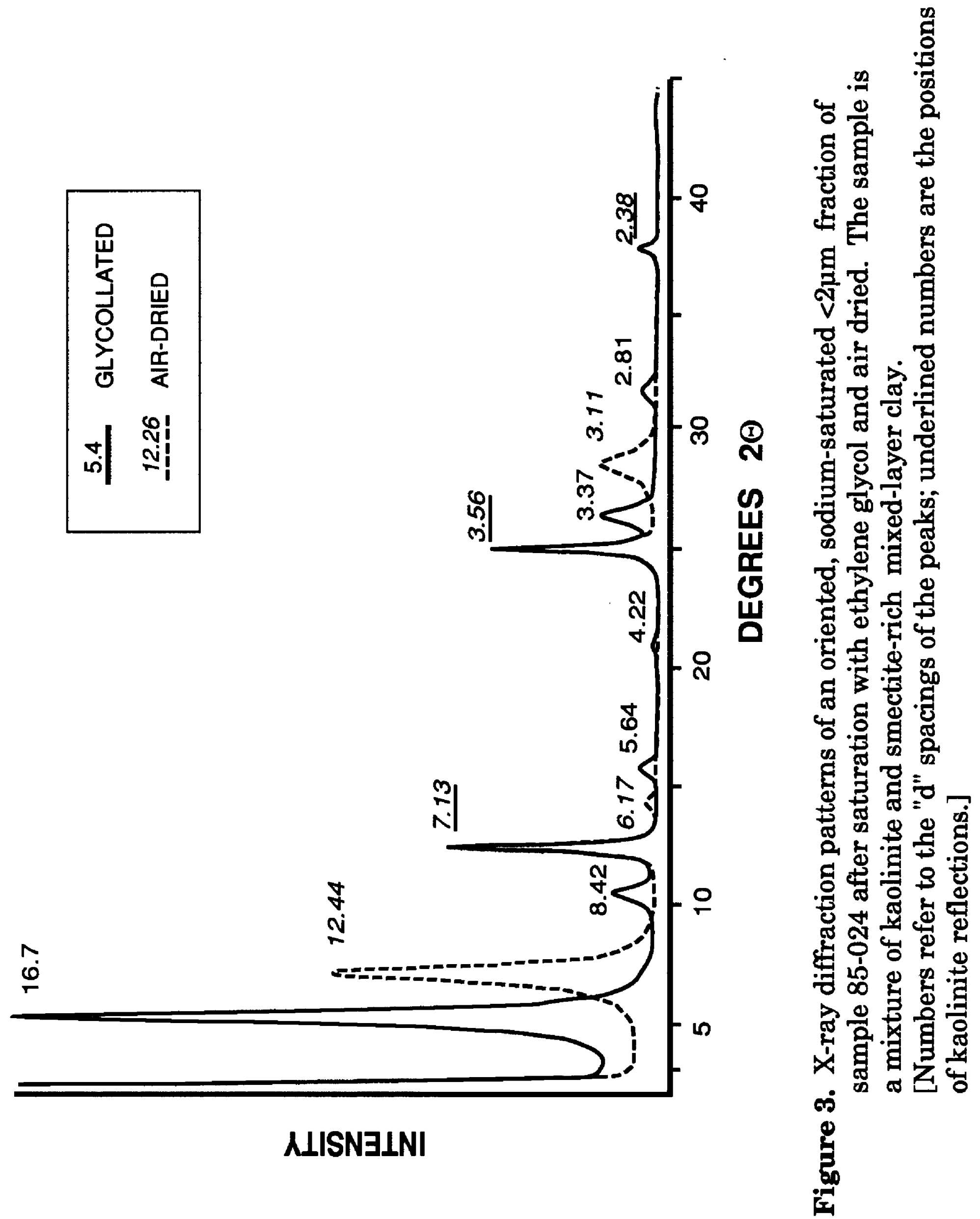
Whole-rock Analyses

\section{Chemical Analyses}

The whole-rock element abundances measured on the Christy samples are listed in appendix 3 and summarized in table 3 . Abundances of 36 elements were determined by inductively-coupled plasma (ICP) spectrometry (Lichte and others, 1987). Ground samples were sintered with sodium peroxide in a zirconium crucible to prepare them for ICP analysis. The sodium peroxide sinter technique was used because of the difficulty in dissolving the iron and titanium oxides, and clays in standard acid treatments. The sinter coke was dropped into water and dissolved by addition of $\mathrm{HCl}$.

Fluorine abundances were determined using the procedure outlined in Jackson and others (1987). A rock sample was fused with $\mathrm{NaOH}$ and subsequently dissolved in water. The resulting solution was buffered with the addition of ammonium citrate and the concentration of fluoride was determined with an ion selective electrode.

Sulfur contents of the samples were measured using a LECO ${ }^{\circledR}$ induction furnace (Jackson and others, 1987). The rock sample is combined with metal accelerators and heated to $1300{ }^{\circ} \mathrm{C}$ with an induction furnace under a stream of oxygen. The evolved sulfur dioxide is then measured with an infrared detector.

\section{Partial Dissolution Analyses}

Four samples (85-008, 85-021, 85-024, 85-026) that contain a range of vanadium abundances were treated with several chemical reagents to selectively dissolve components of the sample and estimate the vanadium content of the dissolved phases. Conditions of reaction and reagents used are summarized in figure 4 and described below. Solutions obtained by the extraction procedures were analyzed for $\mathrm{Al}, \mathrm{Fe}, \mathrm{Mn}$, and $\mathrm{V}$ using standard methods of atomic absorption spectrophotometry. Results are presented in table 4. Because of sample heterogeneity and sample handling, extraction analyses are considered reliable to \pm 15 percent.

The four samples were successively treated with $1 \mathrm{~N}$ ammonium acetate, a mixture of dithionite and citrate (Jackson, 1969), and 4N HCl. Ammonium acetate was applied to determine the abundance of readily exchangeable vanadium. The dithionite-citrate extraction selectively dissolves manganese oxides and weakly to moderately crystalline iron oxides. Four normal HCl was used to dissolve residual iron oxides and poorly crystalline clays. First, 0.5 grams of sample was intermittently shaken with 40 milliliters (ml) of $1 \mathrm{~N}$ ammonium acetate for 8 hours. The suspension settled overnight, was centrifuged, and the solution was decanted, filtered through a $0.4 \mu \mathrm{m}$ filter, and acidified with $2 \mathrm{ml}$ of $2 \mathrm{~N} \mathrm{HNO}_{3}$. The solid residue was then combined with 40 $\mathrm{ml}$ of $0.3 \mathrm{M}$ sodium citrate and $5 \mathrm{ml}$ of $1 \mathrm{M}$ sodium bicarbonate. This solution was placed in a water bath at $75^{\circ} \mathrm{C}$ and 3 successive 1 gram aliquots of sodium dithionite were added at 5 minute intervals. Following the final addition of dithionite, the suspension was cooled and centrifuged. The solution was decanted, filtered, and acidified with $5 \mathrm{ml}$ of $2 \mathrm{~N} \mathrm{HNO}_{3}$. The solid residue was 
Table 3. Summary of whole-rock element abundances. Means and deviations for elements with detection ratios less than one were calculated using the method of Cohen (1961).

[Detection ratio, number of samples above the detection limit/total analyzed; *, determined by ion selective electrode, \#, determined by induction furnace; other elements measured by ICP; n.d., not determined.]

\begin{tabular}{|c|c|c|c|c|c|c|}
\hline Element & Median & $\begin{array}{c}\text { Geometric } \\
\text { Mean }\end{array}$ & $\begin{array}{l}\text { Geometric } \\
\text { Deviation }\end{array}$ & Minimum & Maximum & $\begin{array}{c}\text { Detection } \\
\text { Ratio }\end{array}$ \\
\hline $\mathrm{Al}$ (wt.\%) & 5.2 & 3.04 & 4.0 & 0.11 & 18.5 & $47 / 47$ \\
\hline $\mathrm{Ca}$ (wt.\%) & 0.05 & 0.04 & 3.3 & $<0.02$ & 0.51 & $34 / 47$ \\
\hline $\mathrm{Fe}$ (wt.\%) & 3.7 & 3.48 & 3.4 & 0.21 & 43.9 & $47 / 47$ \\
\hline K (wt.\%) & 0.2 & n.d. & n.d. & $<0.02$ & 3.7 & $25 / 47$ \\
\hline $\mathrm{Mg}$ (wt.\%) & 0.14 & 0.15 & 3.8 & $<0.02$ & 1.74 & $44 / 47$ \\
\hline P (wt.\%) & 0.1 & 0.11 & 2.8 & $<0.02$ & 1.04 & $44 / 47$ \\
\hline Ti (wt.\%) & 1.7 & 0.99 & 6.2 & $<0.02$ & 15.9 & $43 / 47$ \\
\hline $\mathrm{F}^{*}$ (wt.\%) & 0.09 & 0.07 & 3.8 & $<0.01$ & 0.58 & $43 / 47$ \\
\hline S\# (wt.\%) & $<0.01$ & n.d. & n.d. & $<0.01$ & 4.5 & $12 / 47$ \\
\hline $\mathrm{Mn}(\mathrm{ppm})$ & 120 & 177 & 7.1 & 20 & 57200 & $47 / 47$ \\
\hline Ag (ppm) & $<8$ & n.d. & n.d. & $<8$ & $<8$ & $0 / 47$ \\
\hline As (ppm) & $<40$ & n.d. & n.d. & $<40$ & 110 & $11 / 47$ \\
\hline $\mathrm{Au}$ (ppm) & $<30$ & n.d. & n.d. & $<30$ & $<30$ & $0 / 47$ \\
\hline $\mathrm{Ba}(\mathrm{ppm})$ & 267 & 269 & 3.4 & 17 & 3370 & $47 / 47$ \\
\hline $\mathrm{Be}(\mathrm{ppm})$ & 8 & 7.6 & 1.9 & $<4$ & 24 & $38 / 47$ \\
\hline $\mathrm{Bi}(\mathrm{ppm})$ & $<40$ & n.d. & n.d. & $<40$ & $<40$ & $0 / 47$ \\
\hline $\mathrm{Cd}(\mathrm{ppm})$ & $<8$ & n.d. & n.d. & $<8$ & 9 & $1 / 47$ \\
\hline $\mathrm{Ce}$ (ppm) & 40 & 51 & 3.3 & $<20$ & 650 & $39 / 47$ \\
\hline Co (ppm) & $<4$ & n.d. & n.d. & $<4$ & 276 & $22 / 47$ \\
\hline $\mathrm{Cr}(\mathrm{ppm})$ & 59 & 45 & 3.0 & $<4$ & 292 & $43 / 47$ \\
\hline $\mathrm{Cu}(\mathrm{ppm})$ & 24 & 25 & 3.4 & $<4$ & 702 & $42 / 47$ \\
\hline $\mathbf{E u}(\mathrm{ppm})$ & $<8$ & n.d. & n.d. & $<8$ & 75 & $9 / 47$ \\
\hline $\mathrm{Ga}$ (ppm) & 40 & 37 & 2.4 & $<20$ & 230 & $38 / 47$ \\
\hline Ho (ppm) & $<20$ & n.d. & n.d. & $<20$ & 100 & $4 / 47$ \\
\hline $\mathrm{La}(\mathrm{ppm})$ & 18 & 17 & 5.0 & $<8$ & 330 & $31 / 47$ \\
\hline $\mathrm{Li}(\mathrm{ppm})$ & 75 & 71 & 3.0 & $<8$ & 1010 & $45 / 47$ \\
\hline Mo (ppm) & 54 & 60 & 6.6 & $<8$ & 2190 & $40 / 47$ \\
\hline $\mathrm{Nb}$ (ppm) & 220 & 136 & 6.7 & $<20$ & 3160 & $38 / 47$ \\
\hline $\mathrm{Nd}(\mathrm{ppm})$ & 30 & 39 & 2.9 & $<20$ & 370 & $38 / 47$ \\
\hline $\mathrm{Ni}(\mathrm{ppm})$ & 8 & n.d. & n.d. & $<8$ & 116 & $24 / 47$ \\
\hline $\mathrm{Pb}(\mathrm{ppm})$ & $<20$ & n.d. & n.d. & $<20$ & 510 & $18 / 47$ \\
\hline Sc (ppm) & 43 & 39 & 3.3 & $<8$ & 1340 & $43 / 47$ \\
\hline $\operatorname{Sr}(\mathrm{ppm})$ & 153 & 130 & 4.7 & $<8$ & 4200 & $44 / 47$ \\
\hline Th (ppm) & 20 & n.d. & n.d. & $<20$ & 210 & $27 / 47$ \\
\hline $\mathrm{U}(\mathrm{ppm})$ & $<400$ & n.d. & n.d. & $<400$ & $<400$ & $0 / 47$ \\
\hline$V(p p m)$ & 1450 & 1220 & 5.0 & 21 & 27700 & $47 / 47$ \\
\hline$Y(p p m)$ & 58 & 73 & 4.5 & $<8$ & 3540 & $44 / 47$ \\
\hline $\mathrm{Yb}(\mathrm{ppm})$ & 5 & n.d. & n.d. & $<4$ & 167 & $30 / 47$ \\
\hline $\mathrm{Zn}(\mathrm{ppm})$ & 47 & 39 & 4.1 & $<8$ & 591 & $41 / 47$ \\
\hline
\end{tabular}



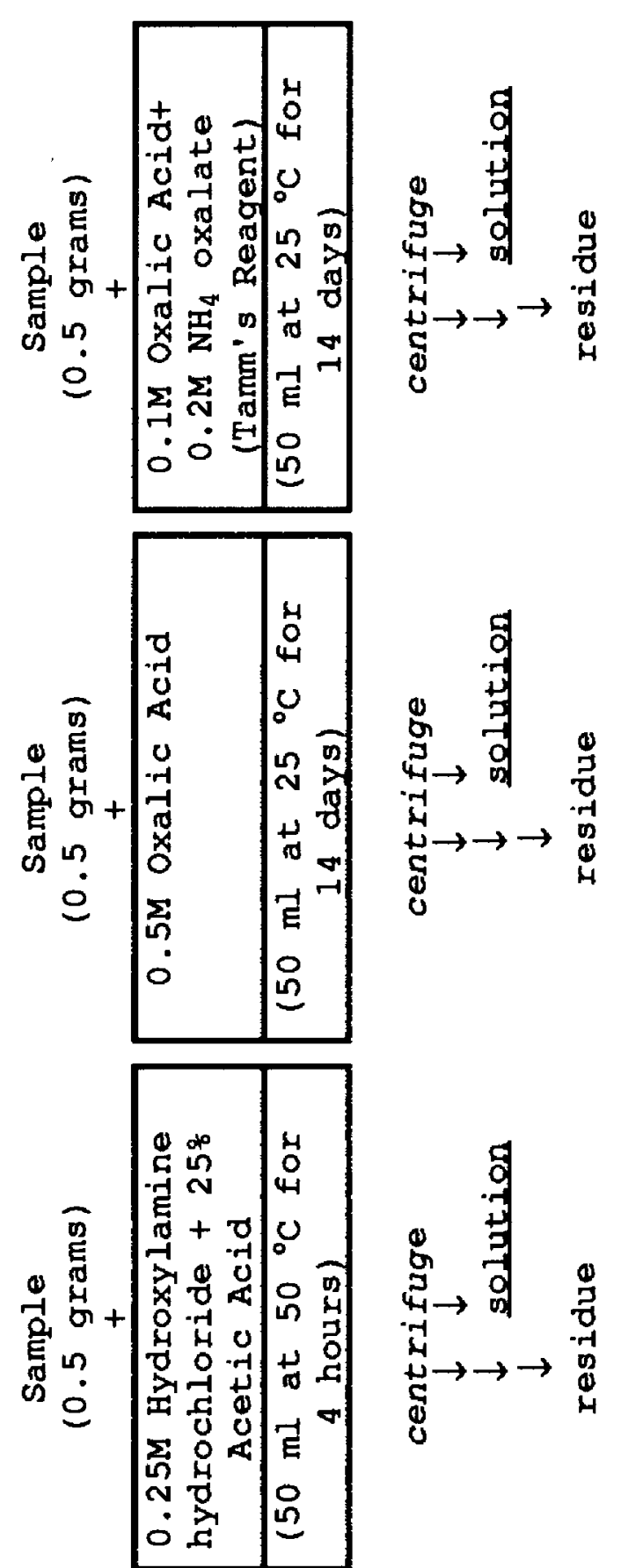

몽

焉

융

题是
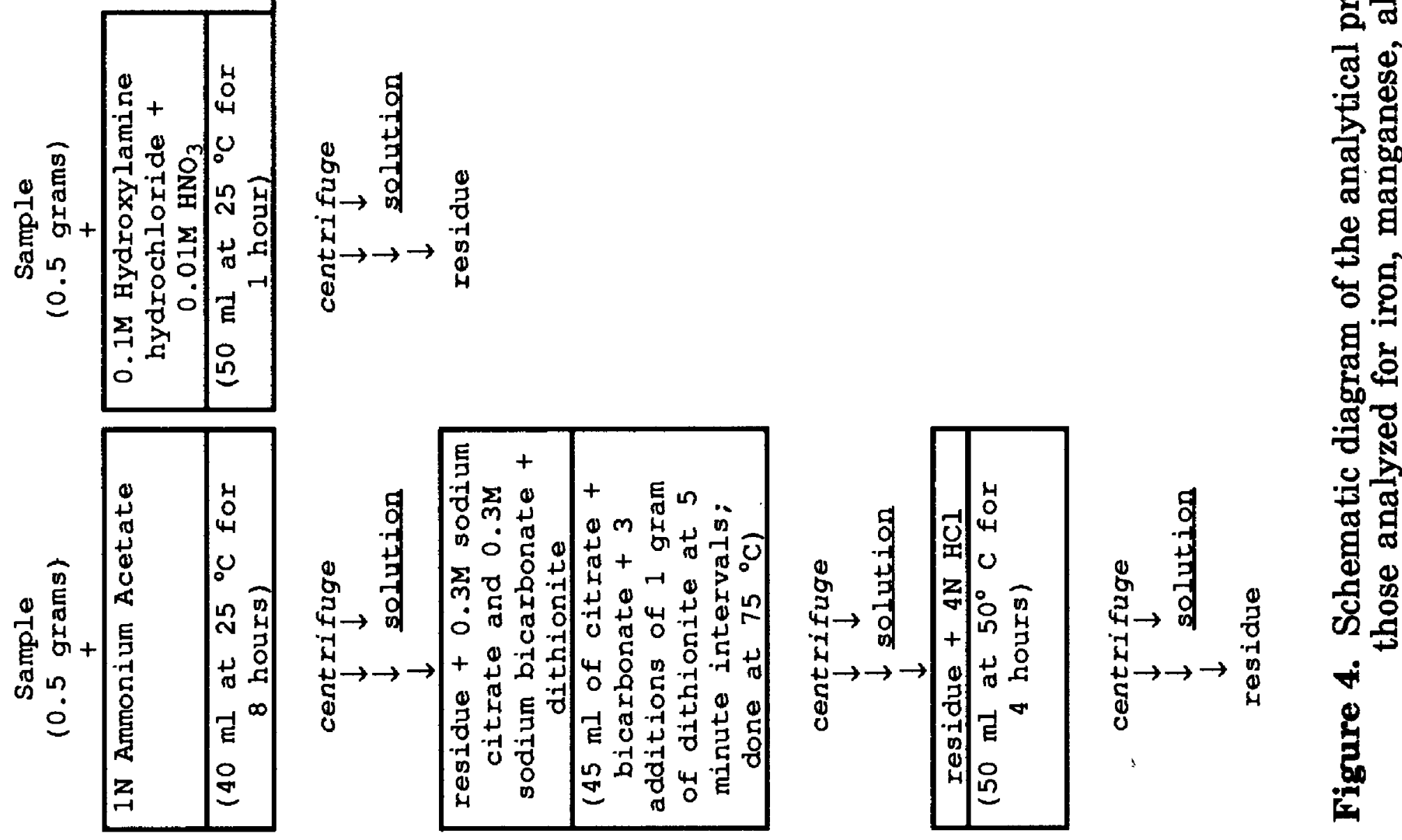


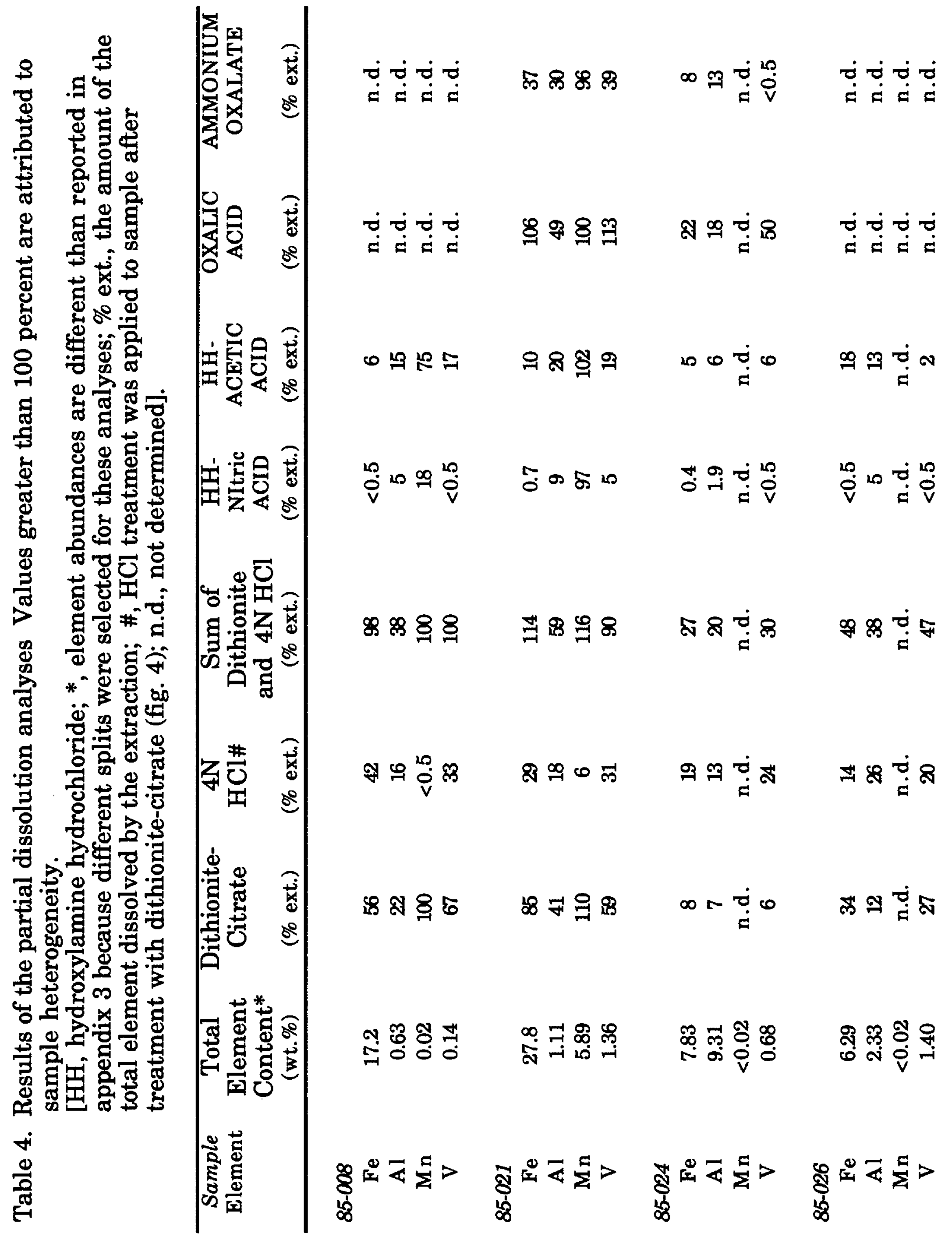


combined with $40 \mathrm{ml}$ of $4 \mathrm{~N} \mathrm{HCl}$ and heated to $50{ }^{\circ} \mathrm{C}$ for four hours. The suspension cooled overnight, and was filtered through a $0.4 \mu \mathrm{m}$ filter.

Two different treatments with hydroxylamine hydrochloride $(\mathrm{HH})$ were used to dissolve manganese and iron oxides. Previous studies indicate that 0.1 $\mathrm{M}$ hydroxylamine hydrochloride in $0.01 \mathrm{M} \mathrm{HNO}_{3}\left(\mathrm{HH}-\mathrm{HNO}_{3}\right)$ selectively dissolves manganese oxides (Filipek and Owen, 1978). One half gram of sample was mixed with $50 \mathrm{ml}$ of this solution and stirred for one hour. After stirring, the suspension was centrifuged and the solution decanted and refrigerated until analyzed. A second 0.5 gram sample was combined with $0.25 \mathrm{M}$ hydroxylamine hydrochloride in $25 \%$ acetic acid (HH-HOAC) to dissolve manganese and amorphous iron oxides (Filipek and Owen, 1978). The mixture was agitated for 4 hours in a water bath, heated to $70^{\circ} \mathrm{C}$ and then centrifuged. The solution was decanted and refrigerated until analyzed.

Two samples (85-021 and 85-024) were treated with oxalic acid and acid ammonium oxalate (Tamm's reagent) to dissolve iron oxides (Jackson, 1969). In the first treatment, $50 \mathrm{ml}$ of $0.5 \mathrm{M}$ oxalic acid solution was added to 0.5 grams of sample and stirred constantly for 14 days. At selected intervals, the suspension was centrifuged and an aliquot of solution was withdrawn. The amount of solution withdrawn was replaced by an equivalent volume of fresh oxalic acid solution to maintain constant volume. The solutions were withdrawn to determine when the extraction was complete. The second oxalic extraction procedure combined $0.1 \mathrm{M}$ oxalic acid and $0.2 \mathrm{M}$ ammonium oxalate to yield a final solution with a $\mathrm{pH}$ of 3.25. A two week reaction time and sampling at selected intervals was also used for this treatment.

\section{Statistical Analysis}

Histograms of nearly all of the chemical data suggested that the data distributions are best approximated as logarithmic. Therefore, geometric means and deviations were calculated according to the methods of Miesch (1976). All other statistical calculations also used logarithmically transformed data. The means and deviations of elements with censored data (abundances below the analytical detection limit) were estimated by Cohen's maximum likelihood technique (Cohen, 1961) provided that the censored data did not exceed 35 percent of the population. Correlation analyses, box plots and the Mann-Whitney U test were calculated using the computer program Statview ${ }^{\mathrm{tm}}$. The Mann-Whitney U test is a nonparametric test to determine whether two data sets are from the same population. For calculation of correlation coefficients and the Mann-Whitney $U$ test censored data was replaced with values equal to 50 percent of the detection limit. Statistics were not calculated for elements having greater than 35 percent censored data. Box plots were used to compare the element abundances among the rock types. Logarithmic scales on box plots were used for elements with large ranges in abundance. 


\section{RESULTS}

Mineralogy

Quartz, kaolinite, smectite, and goethite are the most abundant minerals in the Christy deposit. Common minor phases include adularia, anatase, brookite, illite/mica(?), manganese oxide and pyrite. The relative abundance of these minerals varies greatly among the rock types. Recrystallized novaculite is composed almost exclusively of quartz. Hornfels samples typically contain quartz, adularia, and minor pyrite. Argillized hornfels samples contain abundant smectite, quartz, and kaolinite, minor adularia and a few samples contain minor anatase or brookite. Claystones are mostly smectite with minor amounts of adularia, quartz, and anatase or brookite. The argillized igneous dikes are composed mainly of kaolinite and smectite with minor amounts of anatase. Quartz is notably absent in the dikes. Vuggy quartz veins are composed mainly of quartz, with minor amounts of smectite, kaolinite, brookite and anatase. Gossans are a mixture of quartz and goethite, with minor amounts of smectite, kaolinite and brookite.

Quartz in the Christy deposit ranges from less than $10 \mu \mathrm{m}$ across in the hornfels to doubly terminated euhedral crystals a few centimeters long in quartz veins. The recrystallized novaculite typically contains quartz as large as 0.3 $\mathrm{mm}$ across, in contrast to the $1 \mu \mathrm{m}$ grains typical of the novaculite away from the intrusion (Keller and others, 1984). Grain contacts in the recrystallized novaculite commonly form triple points as described by Keller and others (1984). However, the quartz grains in novaculite sample 85-006 have undulatory extinction, contain abundant inclusions of calcite, and grain contacts are irregular. The unusual appearance of this sample likely reflects alteration related to an adjacent argillized igneous dike. Porous networks of dark quartz crystals as large as two millimeters ( $\mathrm{mm}$ ) are typical of the vuggy quartz samples. These samples may have been novaculite or hornfels that have been severely altered. Some of the vugs are filled with kaolinite or smectite that is believed to be an alteration product of the original interstitial minerals. The surfaces of the quartz crystals in the vuggy quartz are irregular, frosted and have local etch pits suggestive of corrosion. Quartz veins have massive to vitreous silica and commonly contain quartz crystals a few centimeters long; some of these are doubly terminated. The quartz crystals are smoky and clear and are typically zoned. Zoning is marked by inclusions of radiating acicular needles that include a sodium-rich amphibole and pyroxene (Flohr, 1991; Willis, 1992). The last generation of quartz is clear. Some quartz grains are composites based on the variable extinction of domains within crystals. A late silica phase (chalcedony?) forms fine fibers within vugs of some veins.

Kaolinite is abundant in argillized igneous dikes and fills vugs in some porous quartz veins. The kaolinite is white to light pink (the pink color is attributed to a thin coating of iron oxides). Brecciated fragments of argillized dike rock composed mostly of kaolinite are suspended by a gossan matrix near the center of the deposit. These fragments are a few centimeters to a few meters long and most likely formed by alteration of brecciated igneous rock. 
Smectite is the major clay mineral in argillized hornfels and some altered igneous dikes. Claystone samples are composed mainly of smectite, which based on composition (appendix 3 ) resembles a nontronite. The relative abundance of smectite and kaolinite among the samples is attributed to contrasting parent rock compositions. The smectite in the Christy deposit may not be a true smectite based on the X-ray diffraction analysis of the clay separate from sample 85-024. This analysis indicates that the clay is dominantly smectite (80\%) with a small amount of mixed-layering. Overall the XRD results are similar to those obtained by McCormick (1978) for a sample from a vanadium deposit near the Potash Sulfur Springs intrusive complex, which is 7 miles west of the Christy deposit. McCormick concluded that the positions of the (00l) reflections were not rational (Moore and Reynolds, 1989) as a result of a small amount of mixed-layering. Further analysis is necessary to determine the abundance of the mixed-layer phase in other samples. In the absence of these analyses, the expandable clays will be referred to as smectite because that is the dominant component.

Iron and manganese oxides formed from oxidation and dissolution of pyrite, carbonate minerals (Flohr, 1991) and alteration of the iron-rich precursors to the clay minerals. Goethite was the only iron oxide mineral detected by XRD. Goethite forms massive botryoidal accumulations, coatings of variable thickness on clays and quartz, and fine acicular crystals that fill vugs. Goethite also fills fractures that cross both quartz veins and brookite crystals. EDS analyses of goethite in some samples detected significant amounts of vanadium. However, iron oxide psuedomorphs after pyrite had notably low vanadium contents. Manganese oxides are intergrown with goethite and occur both as discrete bands coating fractures and as small areas within massive iron oxides. EDS analyses of manganese oxides indicated only low vanadium contents. The manganese oxide phase was not clearly identifiable by XRD although some reflections consistent with cryptomelane were noted in samples containing greater than three weight percent manganese.

Potassium feldspar, tentatively identified as adularia by XRD, is common in hornfels, and a minor to trace component of argillized hornfels and claystone samples. Petrographic examination of 85-001 indicated that the adularia is smaller than $5 \mu \mathrm{m}$ and difficult to identify. The adularia in these samples is much smaller than the grains of potassium feldspar described by Heathcote (1976) in the Potash Sulfur Springs fenite suggesting that the adularia in the Christy deposit formed under different conditions. The lower abundance of adularia in argillized hornfels likely is due to the alteration responsible for clay formation. The greater abundance of adularia detected in argillized hornfels deeper in the deposit suggests the alteration is partly related to weathering. The abundance of adularia in some claystone samples suggests that claystones may have originally been hornfels that were more intensely argillized.

Brookite and anatase contain most of the titanium in the deposit and these minerals are particularly abundant in vuggy quartz veins and siliceous gossans. The brookite is brown in thin section and forms euhedral crystals within quartz. Some titanium oxide grains have a size and morphology similar 
to brookite but are blue in transmitted light suggestive of anatase (Heinrich, 1965). Brookite crystals that are exposed within a void or on the exterior of a quartz crystal have irregular outlines suggestive of dissolution.

Cubic pyrite crystals are common in hornfels and some argillized hornfels. These rocks contain pyrite disseminated through the rock and in local segregations as long as a centimeter. Within argillized hornfels (90-007), pyrite was concentrated along a fracture perpendicular to layering. Pyrite in sample 85-001 is intergrown with "flames" of an unidentified copper sulfide. Composition of the intergrowth was verified by EDS, but the stoichiometry could not be determined.

Trace amounts of illitic clay and mica were detected in several samples. Within some quartz veins small zones with abundant books of micaceous clay with slightly curved plates were detected. The spectra obtained with the EDS detected high contents of vanadium in some of these micaceous clays. Segregations of morphologically similar micaceous clay were also detected in thin section of a hornfels sample (85-001).

Whole-rock

\section{Chemical Composition}

The intense alteration of rocks in the Christy mine has resulted in the depletion or concentration of many elements. Ideally, to compare rock compositions within the deposit, the element abundance data should be corrected for density changes that result from changes in mineralogy and formation of void space. Unfortunately, most samples are very friable, the volume of the clay-rich samples changes with hydration, and the original compositions of many of the rocks are unknown. Therefore no density correction was attempted. Although the lack of correction limits the usefulness of the data for mass balance calculations, variations in the relative abundances do define systematic trends.

Erickson and Blade (1963) determined that Paleozoic rocks adjacent to the Magnet Cove intrusive complex are enriched in several trace elements including $\mathrm{Sr}, \mathrm{Ba}, \mathrm{La}, \mathrm{Nb}$ and $\mathrm{V}$. In a study of fenitized novaculite near the Potash Sulfur Springs complex Heathcote (1976) determined that K, Na, P, Ca, $\mathrm{Fe}, \mathrm{Ti}, \mathrm{Al}$ and $\mathrm{S}$ were added and Si depleted near the intrusions. Enrichments of many of the same elements were detected in the Christy deposit. Comparisons of abundances of $\mathrm{K}, \mathrm{Al}, \mathrm{Ti}, \mathrm{Nb}, \mathrm{V}, \mathrm{Mo}, \mathrm{Fe}, \mathrm{La}, \mathrm{Ba}, \mathrm{Sr}, \mathrm{Li}$ and $\mathrm{F}$ among the rock-types in the Christy deposit are presented in figure 5. Increases in the abundance of many of these elements are apparently associated with increasing alteration.

The novaculite and hornfels samples are considered the least altered of the rock-types. Although they have been thermally altered, they have not been extensively argillized or oxidized. The novaculite samples are consistently low in all of the elements compared. Relative to the composition of novaculite away from known intrusives (Steuart and others, 1984), samples from the Christy 

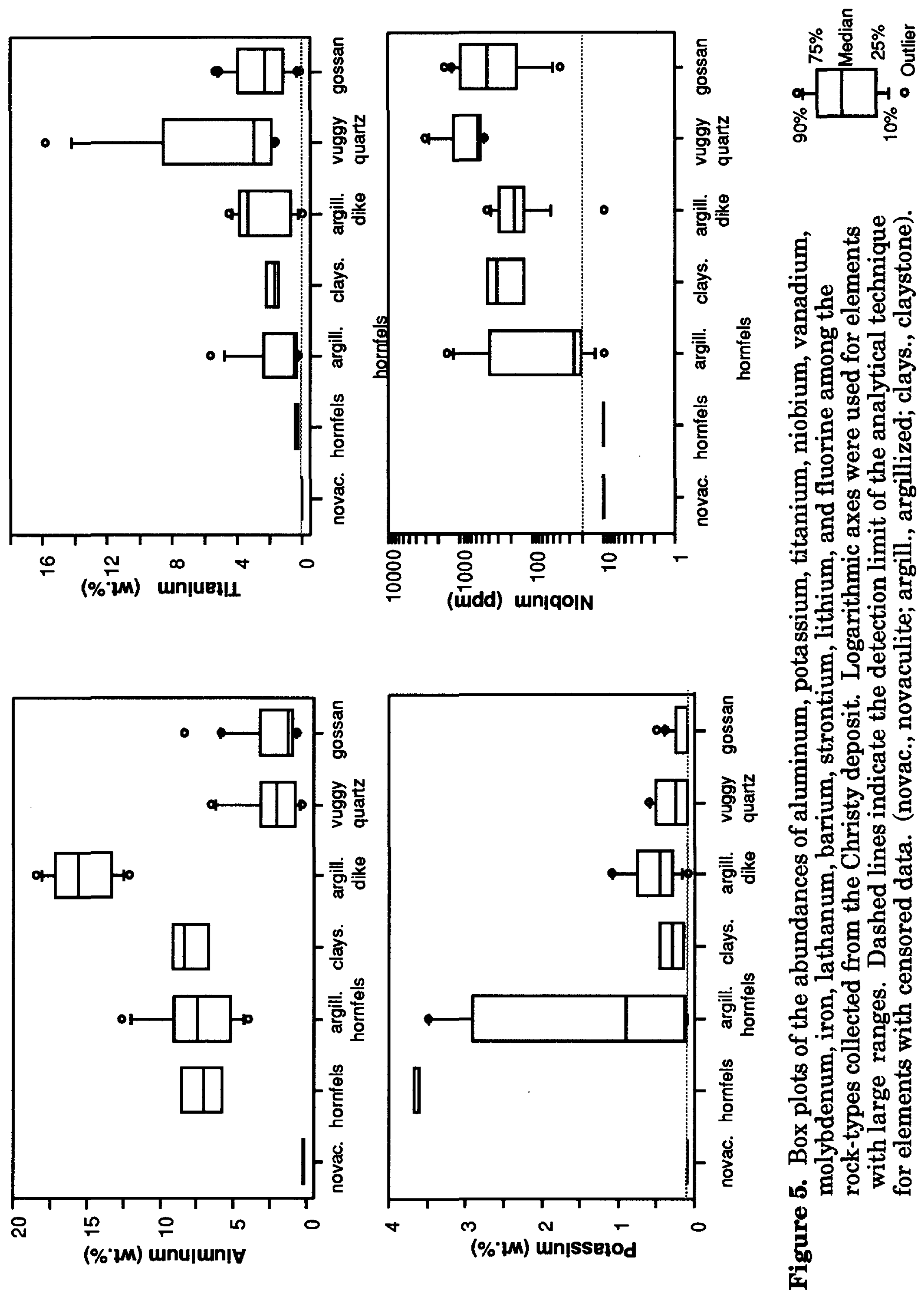

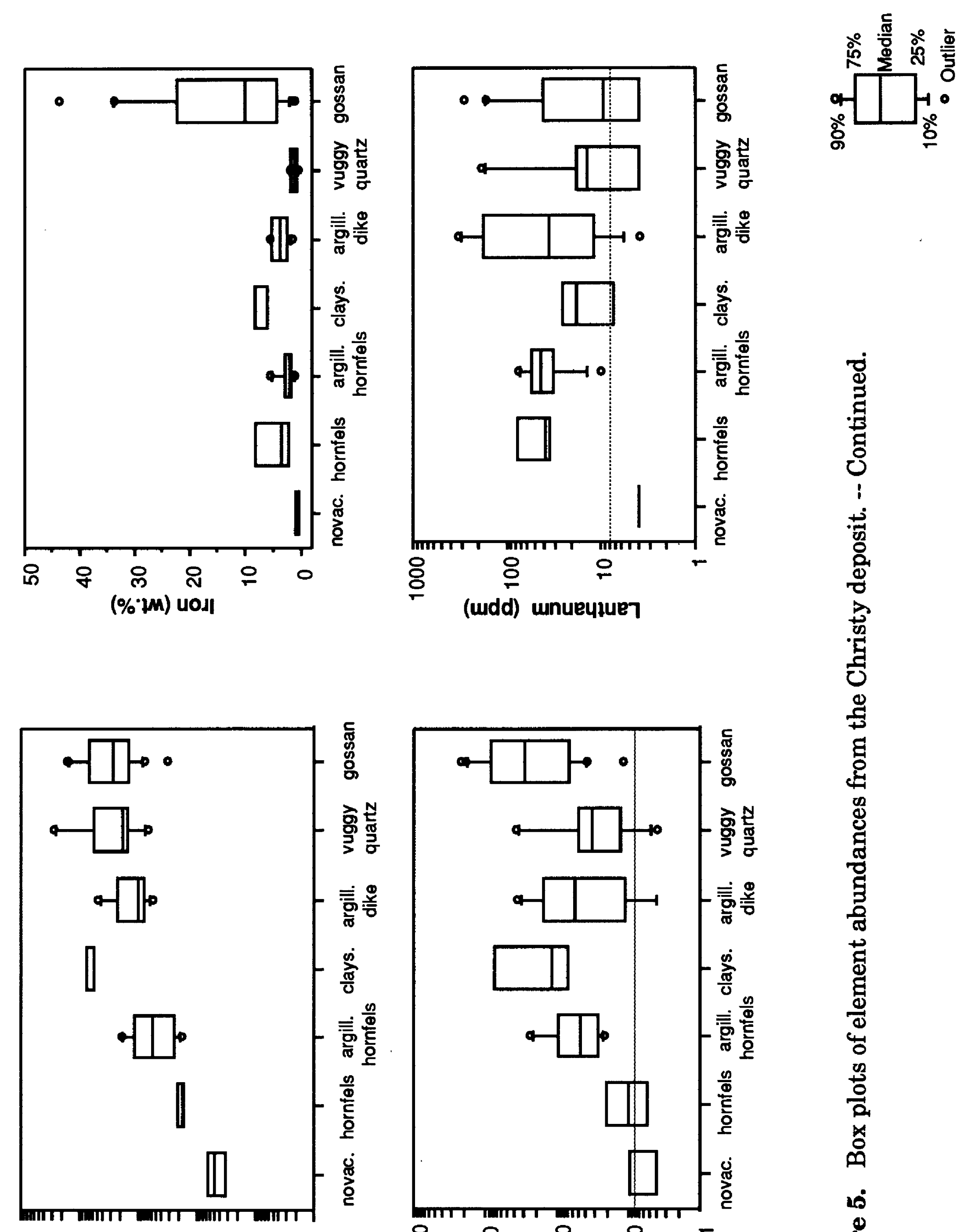

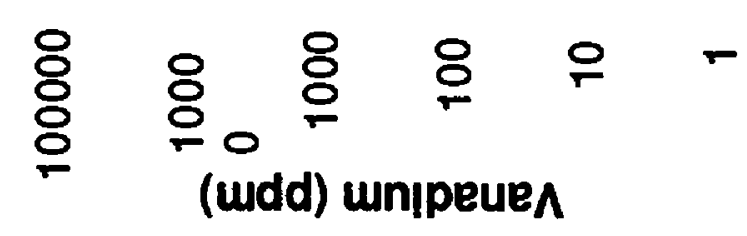

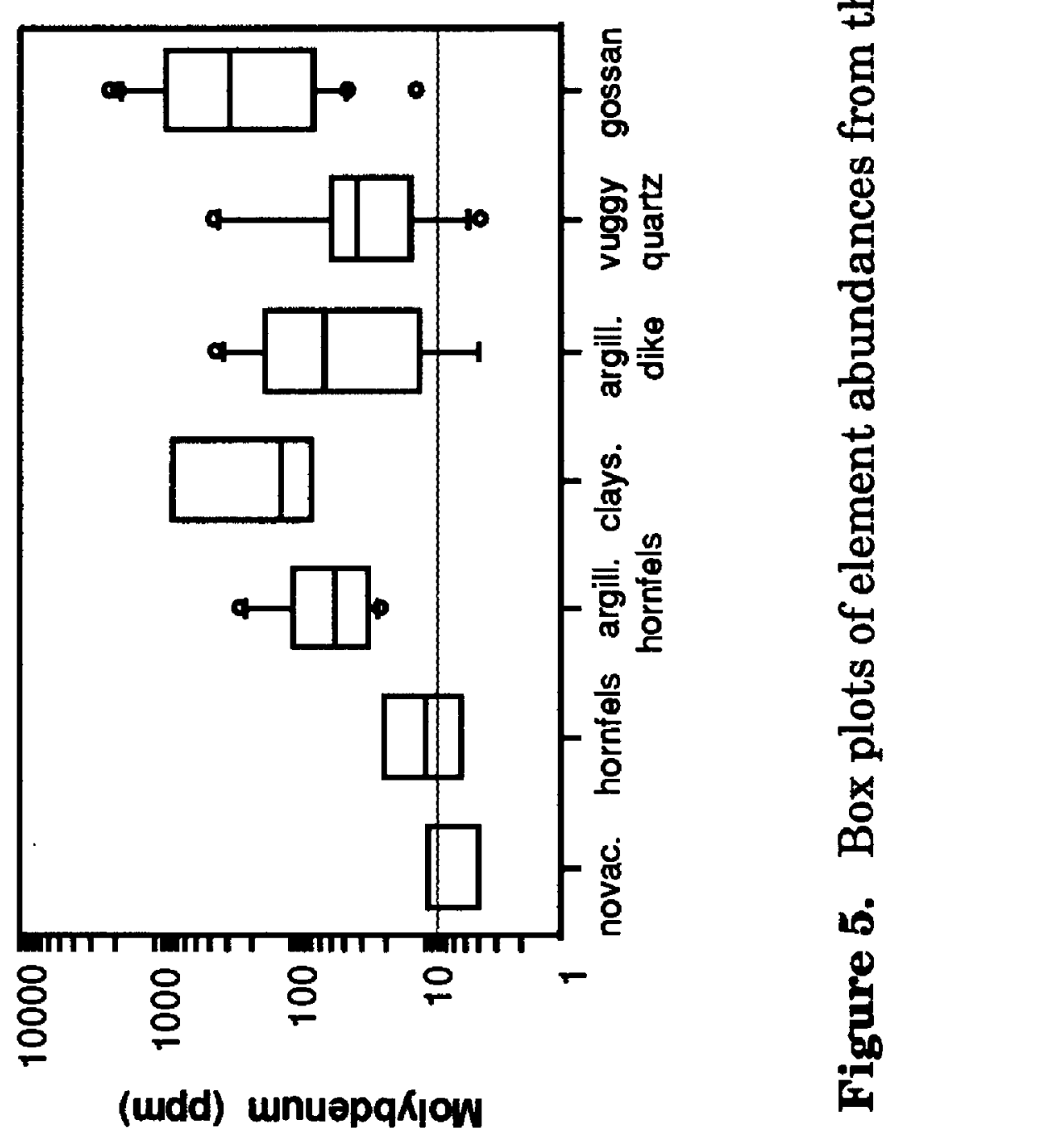




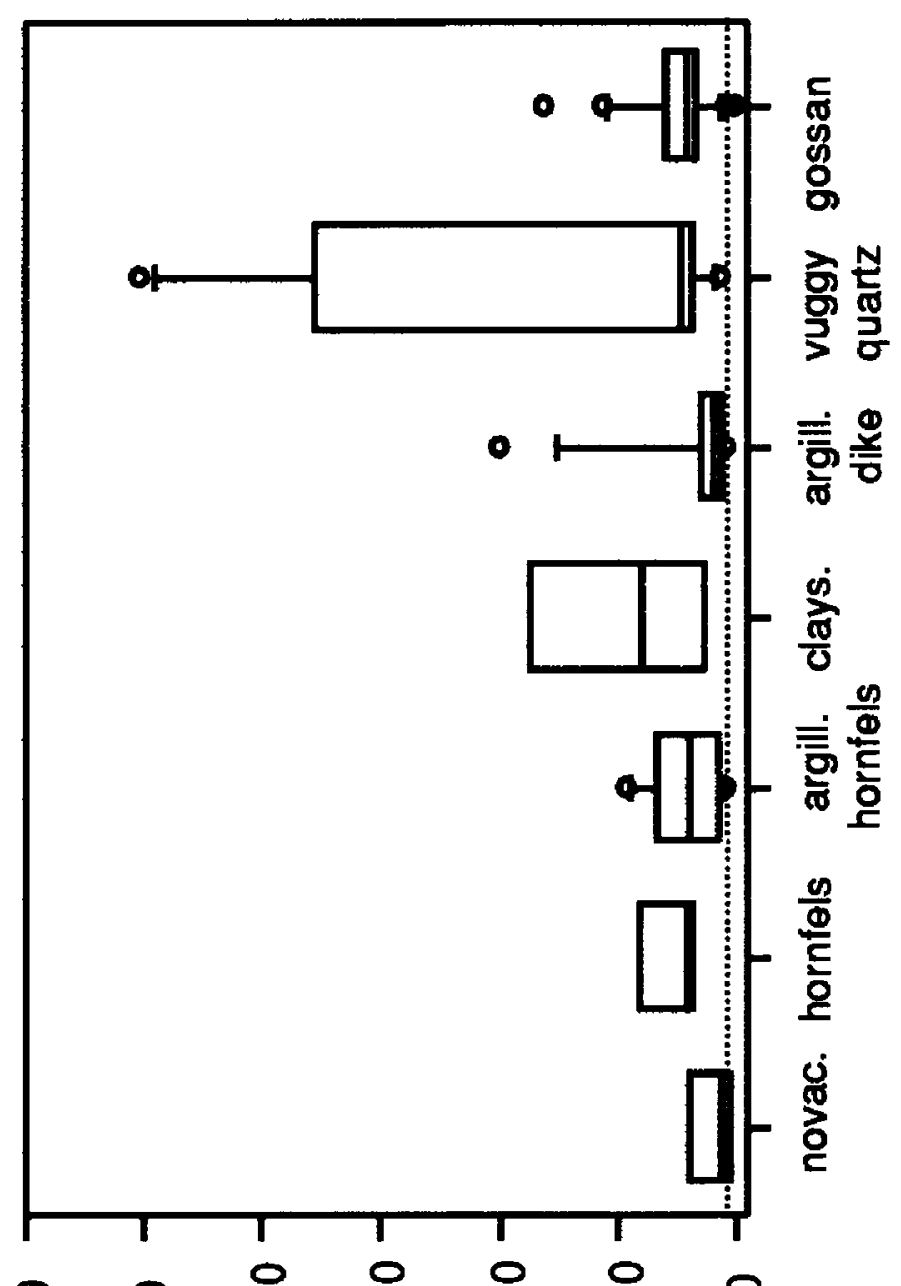

용요용 \&

(udd) un|यमา

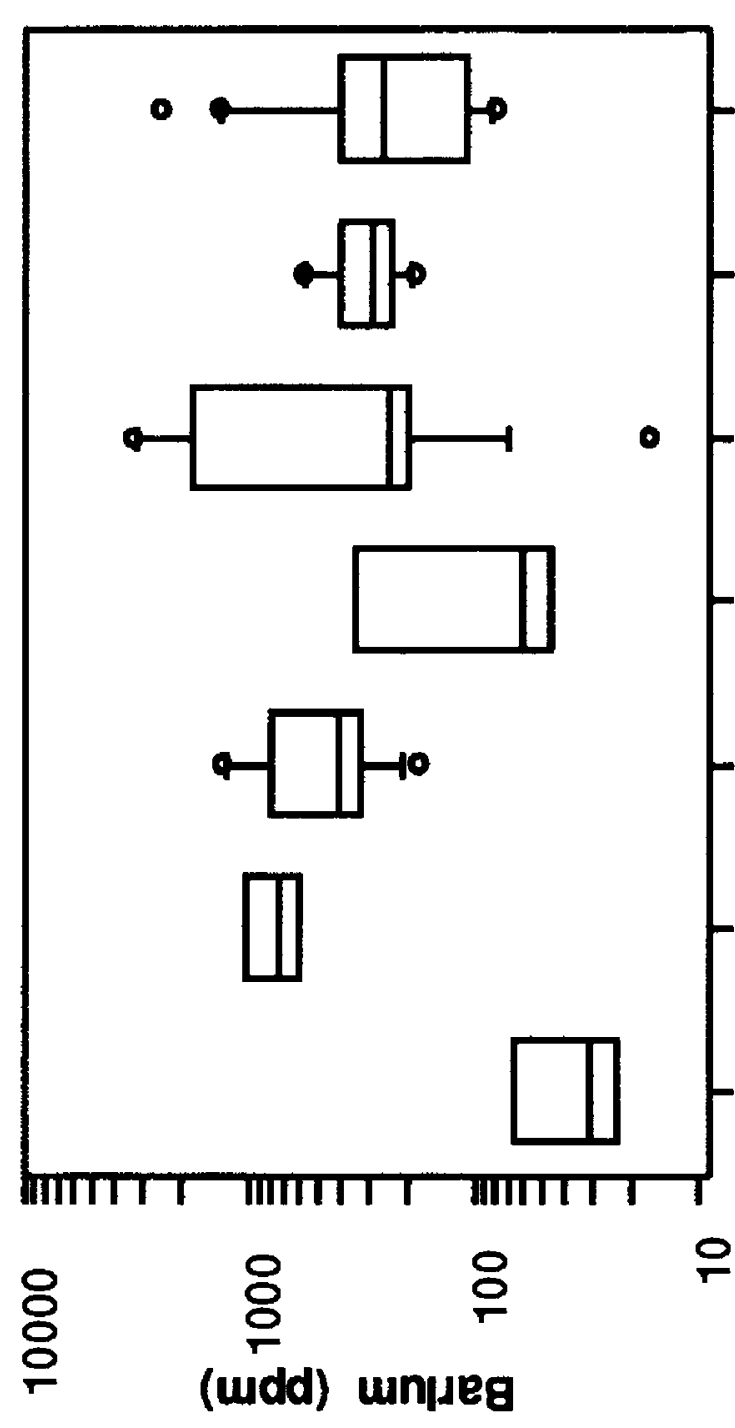

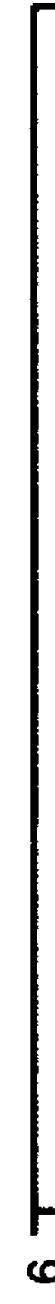

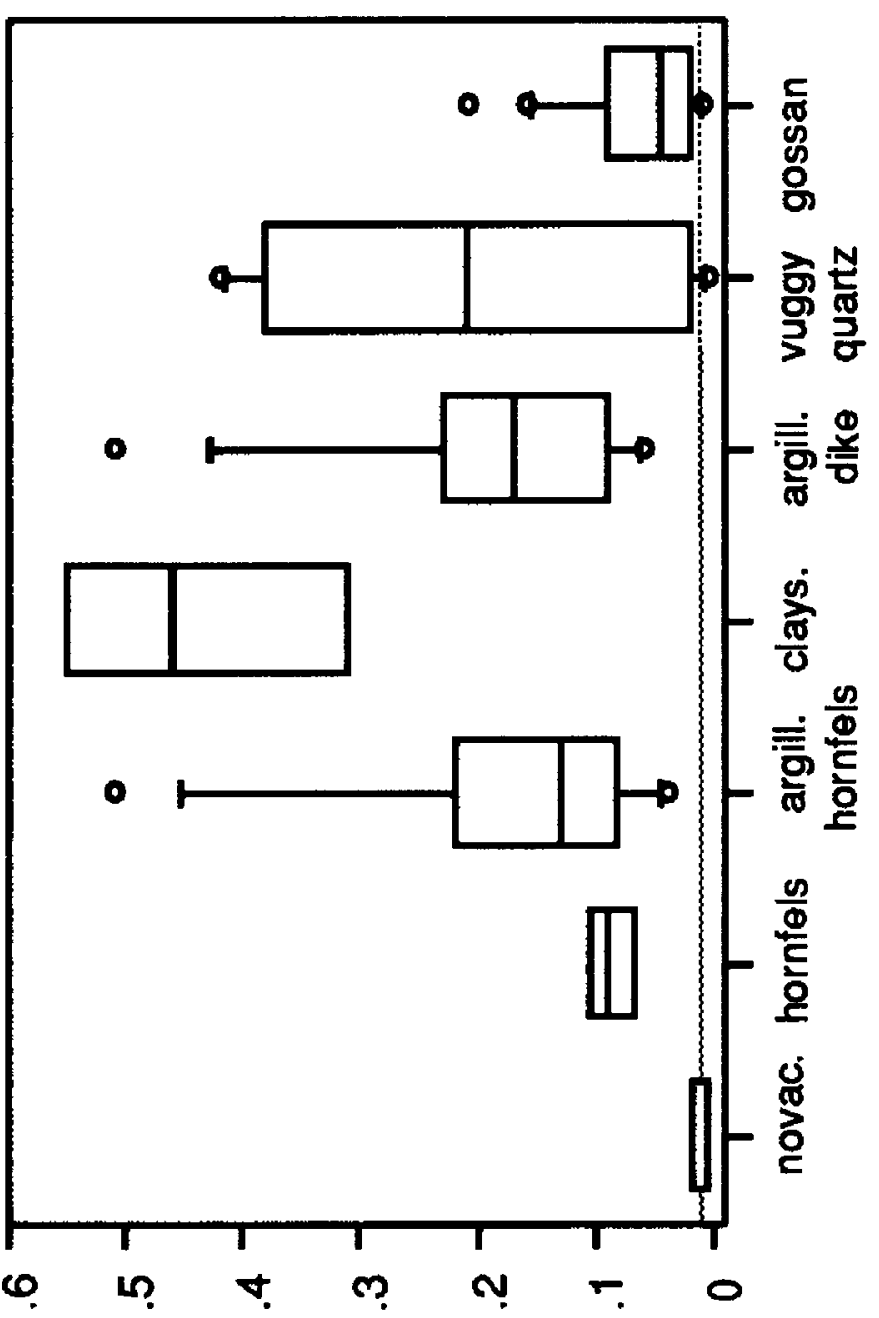

(\%'2m) ouponjy

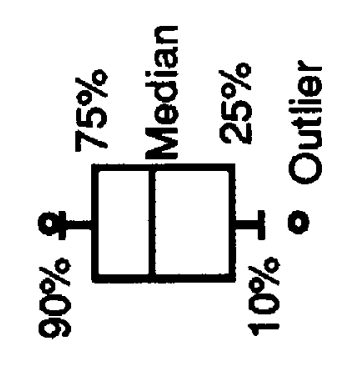



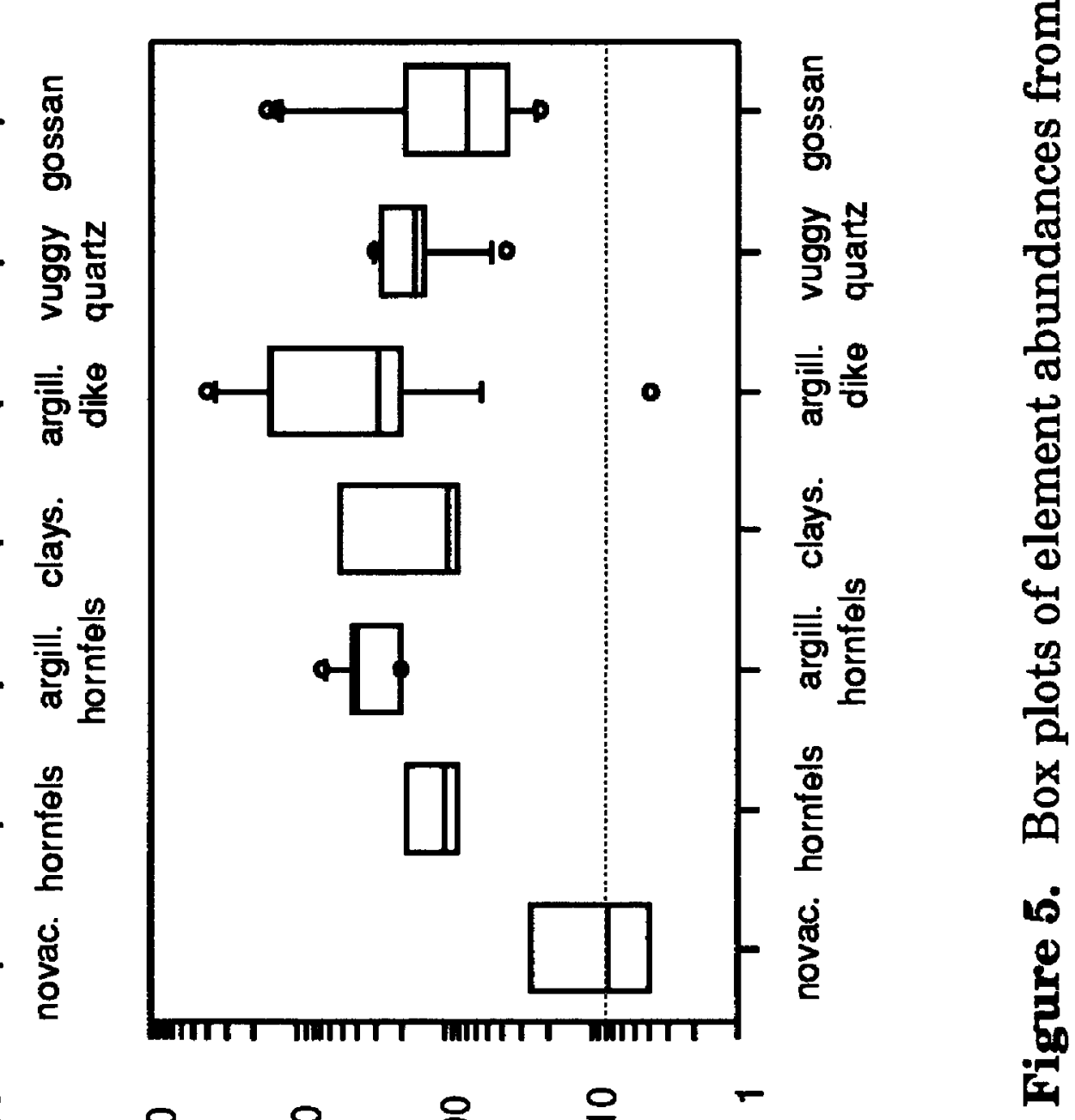


mine have larger $\mathrm{Fe}$ and $\mathrm{Ti}$ contents and smaller $\mathrm{Ca}, \mathrm{K}$, and $\mathrm{Mn}$ abundances. The hornfels samples have the largest $K$ contents, which is consistent with the large abundance of adularia. The hornfels have low contents of $\mathrm{Ti}, \mathrm{Nb}, \mathrm{V}, \mathrm{Mo}$, and $\mathrm{F}$ and high contents of $\mathrm{Ba}$ and $\mathrm{La}$ relative to the more altered rock types (fig. 5). They have significantly lower contents of $\mathrm{Mo}, \mathrm{Nb}, \mathrm{P}, \mathrm{Ti}$ and $\mathrm{V}$ compared to argillized hornfels based on the Mann-Whitney $U$ test.

The hornfels, argillized hornfels and claystones are considered to define a progression in degree of argillic alteration of metamorphosed shales. All three rock types have similar $\mathrm{Al}$ contents but $\mathrm{K}, \mathrm{La}$, and $\mathrm{Ba}$ systematically decrease from hornfels to claystone. In contrast, $\mathrm{Ti}, \mathrm{Nb}, \mathrm{V}, \mathrm{Mo}$, and $\mathrm{F}$ increase toward claystone. The increased concentrations, some as large as 10 fold, cannot be attributed to simple accumulation as a result of weathering. Instead the observed enrichments are attributed to either different hydrothermal solutions, or more intense alteration of parts of the deposit in which hornfels was altered to claystone.

The argillized dikes have the largest contents of $\mathrm{Al}$, and large contents of $\mathrm{Ba}, \mathrm{Sr}$, and $\mathrm{La}$ (and other $\mathrm{REE}$ ). The compositions of the argillized dikes were compared with the tabulations of igneous rock compositions of the Magnet Cove complex (Erickson and Blade, 1963; Flohr and Ross,1990). In general, the argillized dikes contain greater amounts of $\mathrm{Al}, \mathrm{Sc}$ and $\mathrm{V}$ than the Magnet Cove intrusive rocks, whereas $\mathrm{Ca}$ and $\mathrm{Sr}$ are depleted. The behavior of $\mathrm{Sc}$ and $\mathrm{Sr}$ are consistent with a comparison of trace element abundances in saprolite and equivalent fresh rocks by Erickson and Blade (1963). Therefore, these changes in abundance are likely related to weathering reactions, which began in the early Tertiary. The concentrations of other elements overlap with the ranges for the igneous rocks in the intrusive complex and none were considered sufficiently diagnostic to identify the compositions of the precursor igneous rock. The large titanium contents of the argillized dikes is attributed to titanium oxides that most likely formed by alteration of Ti-rich minerals that are common in many of the intrusive rocks of Magnet Cove (Erickson and Blade, 1963; Flohr and Ross, 1990).

Vuggy quartz samples contain the largest $\mathrm{Ti}, \mathrm{Nb}$, and $\mathrm{Li}$ contents and are also enriched in $\mathrm{F}$. The large $\mathrm{Ti}$ and $\mathrm{Nb}$ contents reflect the abundance of brookite in these samples. The abundance of $\mathrm{Li}$ and $\mathrm{F}$ may be attributed to taeniolite $\left(\mathrm{KLiMg}_{2} \mathrm{Si}_{4} \mathrm{O}_{10} \mathrm{~F}_{2}\right)$, which is a component of some veins (Flohr, 1991) and may be intergrown with quartz.

Gossans contain large contents of $\mathrm{Fe}$ and Mo but otherwise are similar to most other altered rocks. Some gossans have large contents of $\mathrm{Ti}, \mathrm{Nb}$, and $\mathrm{V}$. Because gossans were defined by the presence of iron oxides, the overlap with the compositional ranges of most rock-types is considered the result of supergene redistribution of iron beyond the extent of the original iron-bearing minerals The high concentrations of $\mathrm{Mo}$ and $\mathrm{V}$ in some samples is attributed to the tendency of these elements to adsorb and coprecipitate with iron oxides (Kyriacou, 1967; Honeyman, 1984). 
A correlation analysis of the chemical data identified four interelement associations (table 5). Barium, strontium and the rare earth elements (Ce, La, and Nd) define one group, which contains most of the elements identified by Erickson and Blade (1963) as enriched in metamorphosed sedimentary rocks near the Magnet Cove complex. The second association of $\mathrm{Ca}, \mathrm{Mg}$, and $\mathrm{F}$ may reflect the distribution of carbonate minerals or alteration directly related to fluids derived from the carbonatite in the Magnet Cove complex. In the third group, Fe is correlated strongly with $\mathrm{Mo}, \mathrm{Zn}$, and $\mathrm{P}$ and less so with $\mathrm{Mn}$ and V. The weak correlation of $\mathrm{Fe}$ and $\mathrm{Mn}$ may reflect the higher Eh required to form Mn oxides relative to $\mathrm{Fe}$ oxides, or that $\mathrm{Fe}$ and $\mathrm{Mn}$ were not uniformly distributed in the original rocks. The ore elements, $\mathrm{Ti}, \mathrm{Nb}$, and $\mathrm{V}$, form the fourth association and are weakly correlated with Be and Mo.

\section{Partial Dissolution}

Samples selected for treatment by partial dissolution extractions contain abundant iron oxides (85-008; 85-021), abundant clay minerals (85-024), or both (85-026). The amounts of the metals extracted by the various reagents are consistent with both clays and iron oxides hosting most of the vanadium in the deposit (table 4). Only small amounts of vanadium were extracted by the $\mathrm{HH}$ $\mathrm{HNO}_{3}$ extraction, which was used specifically to dissolve manganese oxides.

Specific reactants extracted the vanadium with varying degrees of efficiency. Ammonium acetate did not extract measurable amounts of any of the metals indicating that readily exchangable metals are not present in the deposit. Unlike samples 85-008 and 85-021 in which most of the Fe and V were extracted by the partial dissolution techniques, most of the $\mathrm{Fe}$ and $\mathrm{V}$ in samples 85-024 and 85-026 remained in the solid residue. The lack of extraction suggests these elements reside in resistant sites within clay minerals. The greatest amounts of metal extracted from 85-024 were obtained by the $\mathrm{HCl}$ and oxalic acid reagents. Overall, oxalic acid was most effective at dissolving the elements analyzed. This is partly the result of the long reaction time (14 days). If most of the vanadium in 85-021 is contained in goethite, then the oxalic acid extraction results indicate that the goethite contains 4 weight percent $V$, which is consistent with the results of Flohr (1991). The residence of vanadium depends on the rock type. In argillized rocks, most of the vanadium is bound in clays that may have formed by alteration of originally vanadium-rich silicates. Vanadium in the iron oxide-rich samples is most likely the product of supergene redistribution of vanadium and iron.

\section{IMPLICATIONS FOR DEPOSIT ORIGIN}

Thermal alteration, multiple hydrothermal solutions (Willis, 1992; Willis and others, 1990; 1991) and supergene processes have altered the rocks in the Christy deposit. The relative contribution of these events to the formation of the vanadium ore is difficult to evaluate because of the intensity of the alteration. Flohr and Ross (1990) point out that $\mathrm{Ti}, \mathrm{Nb}$ and $\mathrm{V}$ are compatible elements in the Magnet Cove intrusive complex and accumulated in primary minerals. Autometasomatic reactions may have redistributed a portion of these elements into residual fluids some of which migrated into the country rock, including 


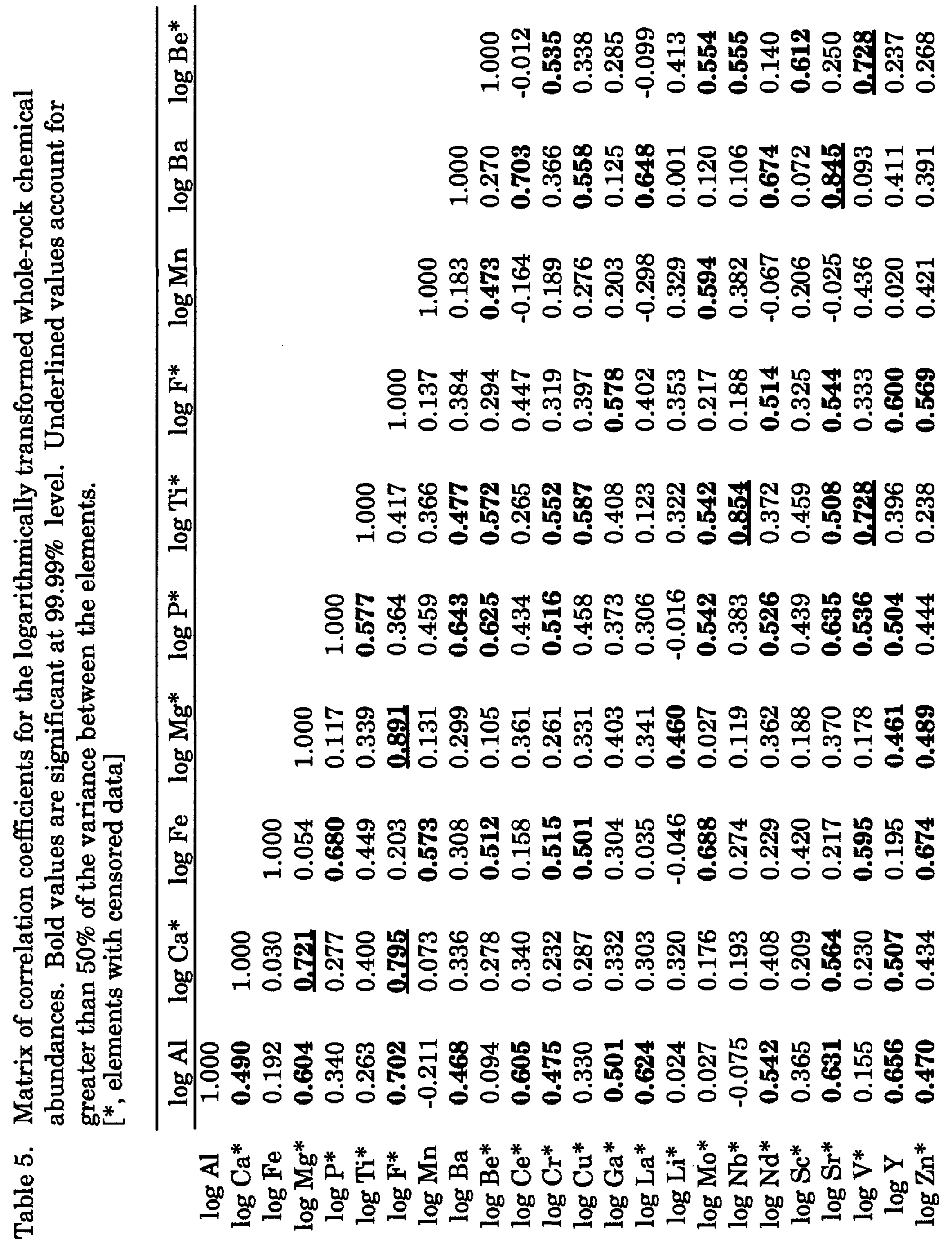



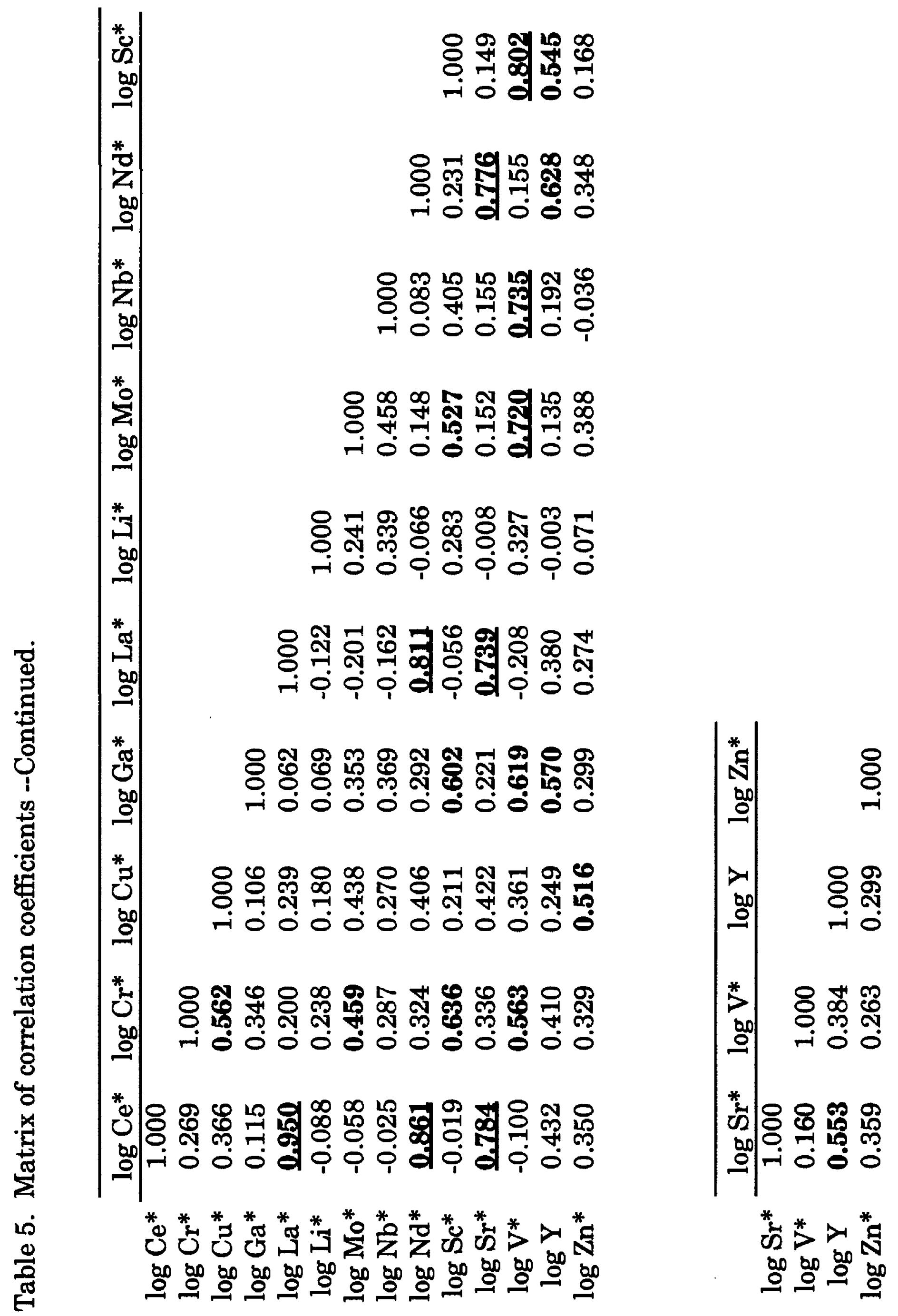
the Christy deposit. Expulsion of the multiple residual fluids generated by the different phases of the intrusive complex (Flohr and Ross, 1990; Flohr, 1991) are recorded by the zoned quartz and fluid inclusions (Willis, 1992). Less permeable blocks of the Paleozoic rocks were altered thermally to form hornfels and recrystallized novaculite. These rocks were only slightly enriched by elements associated with emplacement of the intrusive (Erickson and Blade, 1963). The large accumulations of $\mathrm{Ti}, \mathrm{Nb}$, and $\mathrm{V}$ were restricted to the permeable zones in brecciated rock. Some of the hydrothermal solutions may have been directly responsible for the formation of vanadium-rich smectites and iron oxides (Willis, 1992).

Alteration of the deposit by supergene processes also modified the distribution of vanadium and its abundance in the deposit. Some clay minerals formed during weathering that began in the early Tertiary. Oxidation of pyrite and ferroan carbonates as part of weathering formed goethite. The large concentration of vanadium in the goethite is likely the result of the strong tendency of vanadium to adsorb and coprecipitate with iron oxides (Honeyman, 1984). The original source of the vanadium is unknown but it may have been hosted by clay minerals such as the vanadium-rich smectites, brookite, vanadium oxides (Flohr, 1991) or now absent silicate minerals. The amount of vanadium in the deposits which has resulted from downward movement of vanadium from the weathering of now eroded parts of the deposit is unknown. Further study of the deeper, unoxidized portion of the deposit is necessary to quantify this enrichment.

Acknowledgements:

Access to the Christy mine and vicinity was graciously provided in 1985 by Umetco and in 1990 by Stratcorp. J. Michael Howard of the Arkansas Geological Commission introduced G. Breit to the geology of the area and was invaluable in sampling the deposit. Discussions with Marta Flohr and Malcolm Ross of the U.S. Geological Survey, Marc Willis of the University of Washington, St. Louis, and J. Michael Howard at the Arkansas Geological Commission improved the evaluation of the data. 


\section{REFERENCES}

Cohen, A.C., 1961, Tables for maximum likelihood estimates: Singly truncated and singly censored samples: Technometrics, v. 3, p. 535-541.

Danilchik, Walter, and Haley, B.R., 1964, Geology of the Paleozoic area in the Malvern Quadrangle, Garland and Hot Spring Counties, Arkansas: U.S. Geological Survey Miscellaneous Geologic Investigations Map I405.

Drever, J.I., 1973, The preparation of oriented clay mineral specimens for X-ray diffraction analysis by a filter membrane peel technique: American Mineralogist, v. 58 , p. $553-554$.

Erickson, R.L., and Blade, L.V., 1963, Geochemistry and Petrology of the Alkalic Igneous Complex at Magnet Cove, Arkansas: U.S. Geological Survey Professional Paper 425, 95p.

Filipek, L.H., and Owen, R.M., 1978, Analysis of heavy metal distributions among different mineralogical states in sediments: Canadian Journal of Spectroscopy, v. 23, p. 31-34.

Flohr, M. J. K., 1991, Titanium- Vanadium- and Niobium Mineralization at the Christy Deposit, Magnet Cove Alkaline Igneous Complex, Arkansas: Geological Society of America Abstracts with Programs, v. 23, no. 5, p. A292.

Flohr, M.J.K., and Ross. M., 1989, Alkaline igneous rocks of Magnet Cove, Arkansas: Metasomatized ijolite xenoliths from Diamond Jo quarry: American Mineralogist v. 74, p. 113-131.

Flohr, M.J.K., and Ross, M., 1990, Alkaline igneous rocks of Magnet Cove, Arkansas: Mineralogy and geochemistry of syenites: Lithos, v. 26, p. 67-98.

Fryklund, V.C., Jr., and Holbrook, D.F., 1950, Titanium ore deposits of the Magnet Cove area, Hot Spring County, Arkansas: Arkansas Resources and Development Commission, Division of Geology Bulletin 16, 173p.

Goddard, E.N., Trask, P.D., De Ford, R.K., Rove, O.N., Singewald, J.T., and Overbeck, R.M., 1979 ed., Rock-color chart (1979 ed.): Boulder, Colorado, Geological Society of America.

Gordon, Mackenzie Jr., Tracey, J.I., Jr., and Ellis, M.V., 1959, Geology of the Arkansas bauxite region: U.S. Geological Survey Professional Paper 299, 268p. 
Heathcote, R.C., 1976, Fenitization of the Arkansas Novaculite and adjacent intrusive, Garland County Arkansas: Master's Thesis, University of Arkansas, 56p.

Heinrich, E.W., 1965, Microscopic identification of minerals: New York, McGraw-Hill Book Company, 414p.

Hoelscher, J.E., 1987, Soil Survey of Clark and Hot Spring Counties, Arkansas: U.S. Department of Agriculture and Soil Conservation Service, 266p.

Holbrook, D.F., 1947, A brookite deposit in Hot Spring County, Arkansas: Arkansas Resources and Development Commission, Division of Geology, Bulletin no. 11, 21p.

Hollingsworth, J.S., 1967, Geology of the Wilson Springs vanadium deposits: Geological Society of America Field Conference Guidebook Central Arkansas Economic Geology and Petrology, Arkansas Geological Commission, p. 22-28.

Honeyman, B.D., 1984, Cation and anion adsorption at the oxide/solution interface in systems containing binary mixtures of adsorbents: An investigation of the concept of adsorptive additivity: unpublished $\mathrm{Ph} . \mathrm{D}$. thesis, Stanford University, 246p.

Howard, J.M., 1974, Transition element geochemistry and petrography of the Potash Sulfur Springs Intrusive Complex, Garland County, Arkansas: Master of Science Thesis, University of Arkansas, 118p.

Jackson, M.L., 1969, Soil Chemical Analysis -- Advanced Course 2nd edition, 11 th Printing: Madison Wisconsin, Published by the author, 895 p.

Jackson, L.L., Brown, F.W., and Neil, T.S., 1987, Chapter G, Major and minor elements requiring individual determination, classical whole rock analysis and rapid rock analysis in Baedecker, P.A., ed., Methods for Geochemical Analysis: U.S. Geological Survey Bulletin 1770, p. G1-G23.

Keller, W.D., Stone, C.G., and Hoersch, A.L., 1984, The geologic significance of textures of Paleozoic chert and novaculite in the Ouachita Mountains of Arkansas and Oklahoma, in McFarland, J.D., III, and Bush, W.V., Contributions to the Geology of Arkansas Volume II: Arkansas Geological Commission, Miscellaneous Publication 18-B, p. 87-95.

Kyriacou, Demetrios, 1967, The pH dependence of adsorption of metallic oxyanions by ferric oxide powder: Surface Science, v.8, p.370-372.

Lichte, F.E., Golightly, D.W., and Lamothe, P.J., 1987, Chapter B Inductively coupled plasma-atomic emission spectrometry in Baedecker, P.A. ed., Methods for Geochemical Analysis: U.S. Geological Survey Bulletin 1770, p. B1-B10. 
McCormick, G.R., 1978, Vanadium-titanium-bearing mixed layer clay from Potash Sulfur Springs, Arkansas: Clays and Clay Minerals, v. 26, no.2, p. 93-100.

Miesch, A., 1976, Sampling designs for geochemical surveys, syllabus for a short course: U.S. Geological Survey Open-file report 76-272, 130p.

Moore, D.M., and Reynolds, R.C., 1989, X-ray diffraction and the identification and analysis of clay minerals: New York, Oxford University Press, $332 \mathrm{p}$.

Reed, D.F., 1949, Investigation of Christy Titanium deposit, Hot Spring County, Arkansas: U.S. Bureau of Mines Report of Investigation 4592, 10p.

Steele, K.F., and Wagner, G.H., 1976, Minerals Availability System: Vanadium, titanium, columbium and tantalum resources of Arkansas: Report to the U.S. Bureau of Mines, Grant No. G0155021, 9p.

Steuart, C.T., Holbrook, D.F., and Stone, C.G., 1984, Arkansas Novaculite: Indians, Whetstones, Plastics and Beyond in McFarland, J.D., III, and Bush, W.V.,eds., Contributions to the Geology of Arkansas, Volume II: Arkansas Geological Commission, Miscellaneous Publication 18-B p. 119-134.

Toewe, E.C., Schatz, R.W., Carmichael, R.L., and Goldberger, W.M., 1968, Evaluation of columbium-bearing rutile deposits, Magnet Cove, Arkansas: Final Report, Phase A, Batelle Memorial Institute, 75 p.

Williams, J.F., 1891, The igneous rocks of Arkansas: Annual Report of the Geological Survey of Arkansas for 1890, Volume 2, 457p.

Willis, M.A., 1992, Calculation of thermodynamic properties of aqueous titanium species and constraints on the mobility of $\mathrm{Ti}$ in aqueous solution in geologic environments: Master of Arts Thesis, Washington University, St Louis, 323p.

Willis, M.A., Pasteris, J.D., and Schock, E.L., 1990, Hydrothermal transport of titanium as exemplified by quartz-titanium dioxide veins near Magnet Cove, Arkansas: Geological Society of America Program with Abstracts, v.22, no.6, p. 363.

Willis, M., Pasteris, J.D., and Schock, E.L., 1991, Microanalytical investigation of the titanium mineralization at Magnet Cove, Arkansas and possible mechanisms for titanium transport: Geological Society of America Program with Abstracts, v. 23, no.6, p. 291-292.

Zartman, R.E., 1977, Geochronology of some alkalic provinces in eastern and central United States: Annual Review of Earth and Planetary Sciences, v. 5, p. 257-286. 
Appendix 1. Descriptions of samples from the Christy vanadium-titanium deposit and vicinity. Colors were determined by comparing the color chart of Goddard and others (1979) with samples ground to less than $150 \mu \mathrm{m}$. Italics indicate sample location and color.

SAMPLE DESCRIPIION

85-001 pyritic hornfels; west end, on floor of 520' level; Color 5Y9/1

hornfels with $<2 \mathrm{~cm}$ thick alternating white and light gray layers; gray layers are siliceous; white layers are slightly argillaceous; cubes of pyrite are disseminated through the sample ( $\sim 1$ percent); subparallel to the layers are thin $(<0.5 \mathrm{~mm}$ wide) veinlets of vitreous gray silica.

85-002 novaculite; representative of a block bounded by argillized dikes, sample was collected 6 feet from nearest recognized igneous dike; west wall between $520^{\prime}$ and 560 ' levels; Color 5GY7/1

gray, fine grained, granular quartzite; cross cut by small fractures and thin $(<0.5$ $\mathrm{mm}$ ) veinlets of "bleached", white novaculite. Fractures have thin coatings of orange-yellow iron oxides.

85-003 argillized igneous dike; 2 feet wide, dike is slightly offset by a fault; west wall between 520' and 560' levels; Color 10YR 8/6

white and yellow-brown clay; disseminated yellow-brown iron oxides are common and locally fill vugs; red-brown iron oxides stain the sample in thin tubes and veinlets (root zone?).

85-004 novaculite; collected within 2 feet of the contact with an argillized igneous dike (85-003), same block as sample 85-002; west wall between 520' and 560' levels; Color $5 Y 7 / 3$

gray, fine-grained granular quartzite; the sample is cut by numerous fractures that have white haloes; orange-brown iron oxides are disseminated through the quartzite and coat fractures.

85-005 brecciated gossan; adjacent to an argillized igneous dike (85-003); west wall between 520' and 560' levels; Color 10YR6/4

friable gossan composed of dark gray vuggy quartz and euhedral quartz grains, orange clays and orange-brown iron oxides; minor brookite in the quartz

85-006 white novaculite; adjacent to argillized dike; west wall between $520^{\prime}$ and $560^{\prime}$ levels; Color 5YR8/6

light gray, fine grained, granular quartzite, that is crossed by thin fractures lined with orange-brown iron oxide; thin $(<5 \mathrm{~mm})$ bleached haloes surround the fractures.

85-007 argillized igneous dike; 2 feet wide that is cross cut by other dikes; west wall between 520' and 560' levels; Color 5Y8/2

white to yellow-green clay; color variations suggest an originally porphyritic texture. The matrix is light yellow and "phenocrysts" are yellow-green with some iron oxides. 


\section{Appendix 1. Sample descriptions--Continued}

SAMPLE DESCRIPTION

85-008 siliceous gossan; from the center of an argillized dike; west wall between 520' and 560' levels; Color 10YR5/5

dark yellow-orange to brown gossan composed of massive smokey quartz and clear quartz crystals, some of which are doubly terminated; massive quartz is coated with brown-black iron oxides and clays; yellow-orange iron oxides fill vugs.

85-009 argillized igneous dike; west wall between 520' and 560' levels; Color 5YR8/4 massive light purple to buff clay

85-010 vein quartz and vug-filling clay; from a zone underlying a block of recrystallized novaculite; west wall between 520' and 560' levels; Color 5YR4/4

black to dark gray, massive to vuggy quartz intermixed with a porous network of fine grained subhedral quartz crystals; some vugs are filled with white clay and some are filled or stained with yellow-brown to red iron oxides; trace amounts of small brookite crystals are intergrown with the quartz

85-011 gossan; interlayered with quartz and clay (85-010); west wall between 520' and 560' levels; Color 10YR6/5

yellow-brown iron oxides, clays and black to clear vitreous quartz; some quartz crystals are euhedral

85-012 siliceous gossan; same zone as (85-011); west wall between 520' and 560' levels; Color 10YR7/3

dark gray to black porous ( $40 \%$ porosity) aggregate of $1 \mathrm{~mm}$ quartz grains(crystals?); the pore space is filled with white clay and iron oxides; pore-filling iron oxide is massive black-brown; small grains of brookite are intergrown with quartz

85-013 argillized igneous dike; contains layers of quartz crystals; west wall between 520' and 560' levels; Color $5 Y 8 / 3$

yellow-brown iron oxide stained white clay and vuggy gray vein quartz; disseminated fine to medium grained quartz and small crystals of brookite; quartz and brookite are suspended in the clay; vugs in quartz vein are lined with euhedral quartz crystals and small brookite crystals, some vugs are filled with white clay

85-014 argillized igneous dike; contains a zone of black quartz and brookite; west wall between 520' and 560' levels; Color 10YR6/3

white clay with disseminated inclusions of dark gray-brown clay and a few small crystals of clear quartz.

85-015 argillized hornfels; alternating white and gray layers are composed mainly of clay; collected within 2 feet of an argillized igneous dike (85-013); west wall between $520^{\prime}$ and 560' levels; Color 5Y7/1

network of small ( $2 \mathrm{~mm}$ long) black quartz crystals infilled with light gray-green waxy or white clay; small brookite crystals line some voids; minor orange-brown iron oxide as stain and pore-filling 


\section{Appendix 1. Sample descriptions--Continued}

SAMPIE DESCRIPTION

85-016 gossan; surrounds argillized block of brecciated igneous dike?; ore zone, wall between 520' and 540' levels; Color 10YR5/6

friable gossan; a mixture of iron oxide; clay and a few clear quartz crystals; white iridescent clay(mica?) fills some vugs that contain brookite

85-017 argillized east-trending igneous dike; dark gossan surrounds the dike; ore zone, wall between 520' and 540' levels; Color 10YR8/4

white clay; color variations are pseudomorphic after a "porphyritic" texture, the texture is suggested by a light green clay "phenocrysts" in a buff matrix; clay matrix contains disseminated iron oxides $<0.1 \mathrm{~mm}$ in diameter; $a$ few of the iron oxides resemble cubes (after pyrite?)

85-018 gossan; collected within 3 feet of an argillized igneous dike (85-017); ore zone, wall between 520' and 540' levels; Color 10YR5/ 6

Siliceous gossan; vuggy quartz vein that is coated with yellow iron oxides, vugs are filled with variable amounts of orange clay and brown iron oxides that locally form a boxwork; minor brookite occurs within the quartz.

85-019 massive clay; nontronite(?) (extensively argillized hornfels?); ore zone, wall between 520' and 540' levels; Color $5 Y 8 / 3$

massive light-green clay with small grains of gray to clear vitreous quartz and disseminated brookite; a thin coating of yellow-orange iron oxides coats most quartz grains.

85-020 claystone; nontronite(?) (extensively argillized hornfels?); ore zone, in wall between $520^{\prime}$ and 540' levels; Color 5GY7/1

gray-green and white clay; a few disseminated quartz(?) grains.

85-021 gossan; 3 feet west of 85-019, sample is banded by alternating layers of clay and iron oxide that are a few $\mathrm{cm}$ thick; ore zone, wall between 520' and 540' levels; Color 10YR4/6

siliceous gossan; vuggy quartz vein coated with orange-brown iron oxides; locally the coatings are massive silver gray and metallic; vugs in quartz are filled with thin "rods" of iron oxide.

85-022 argillized hornfels(?); ore zone, wall between 520' and 540' levels; Color 10YR7/4 mixture of quartz, yellow-green clays and yellow-brown iron oxides; brookite is mixed with quartz in massive white clay; some quartz is doubly terminated

85-023 brecciated siliceous gossan; ore zone, wall between 520' and 540' levels; Color $10 \mathrm{YR} 5 / 5$

chalcedony(?) cemented clasts of granular quartzite, red-brown shale(?) and pockets of white micaceous clay; quartz vein and euhedral quartz crystals with minor brookite; sample is coated with yellow-brown iron oxides. 


\section{Appendix 1. Sample descriptions--Continued}

SAMPLE DESCRIPTON

85-024 gray claystone; nontronite(?); (extensively argillized hornfels?) 15 feet north of 85023 ; ore zone, wall between 520' and 540' levels; Color $5 Y 8 / 3$

massive light to dark green claystone; darker portions of the sample are harder; clay contains disseminated quartz crystals and yellow-brown iron oxides.

85-025 argillized igneous dike; dike fragments ( 3 feet by 2 feet) are surrounded by siliceous gossan; ore zone, wall between $520^{\prime}$ and $540^{\prime}$ levels; Color 10YR8/3 white clay banded with light iron oxide bands (Liesegang bands) that are as wide as $5 \mathrm{~mm}$; small cubes of brown iron oxide are disseminated in the clay (after pyrite?)

85-026 gossan; surrounding 85-025; ore zone, wall between 520' and 540' levels; Color 10YR3/2

dark red to black, massive siliceous gossan; scattered quartz crystals are coated with thick layers of brown iron oxides; some white clay in vugs is also stained; crystals of brookite are dissminated in some vugs.

85-027 argillized hornfels; ore zone, wall between $520^{\prime}$ and 540' levels; Color 10YR9/4 massive, white silty clay; sample is harder than other argillized rocks; contains a trace of very fine-grained opaque grains disseminated through the sample.

85-028 vuggy quartz; black quartz crystals mixed with clay; ore zone, wall between 520' and 540' levels; Color N8

a mixture of nearly equal amounts of black quartz and massive green waxy clay; fine-grained cubes of brookite are mixed with the clay; some of the quartz is euhedral

85-030 vuggy quartz; recrystallized novaculite(?) along contact with 85-028; ore zone, wall between $520^{\prime}$ and 540' levels; Color 5 Y6/ 1

porous (40 percent void space) network of black quartz crystals as large as $1 \mathrm{~mm}$; some crystals are coated with white clay; vugs are filled with light-yellow brown clay; some are lined with fine-grained brookite

85-031 gossan; fills fracture zone between blocks of novaculite; east wall between 560' and $590^{\prime}$ levels; Color 10YR6/4

a mixture of clays, quartz crystals and yellow-orange-brown iron oxides; clays are iron stained red/brown; yellow-brown iron oxides cement a breccia zone of sand-sized grains.

85-032 novaculite; collected 10 feet north of 85-031; east wall between 560' and 590' levels; Color 5Y7/1.

massive, dark gray fine-grained quartzite; red to yellow iron oxides coat the fractures and are disseminated through the sample.

85-033 gossan; fracture-filling between two large blocks of recrystallized novaculite; east wall between 560' and 590' levels; Color 10YR7/5

breccia(?) composed of yellow-green to white clay that is stained with red iron oxides, and gray quartz that includes euhedral crystals and granular fragments. 
Appendix 1. Sample descriptions--Continued

SAMPLE DESCRIPTION

85-034 hornfels; from northwest bench at the 540' level; Color 5Y7/3 gray-green fractured, slightly argillized hornfels; red iron oxides coat some fracture surfaces; sample is crossed by thin veinlets of vitreous gray silica.

90-001 gossan; northeast wall between 500' and 520' levels; Color 10YR5/6 vuggy, siliceous gossan; clear to gray quartz with inclusions of dark green acicular crystals; quartz is coated with dark brown-black metallic oxides; orange-yellow iron oxides coat fractures and open spaces; some vugs are filled with orange-brown clay.

90-002 argillized igneous dike; dike is east-trending and is laterally continuous from sample site 86-017; east wall between 500' and 520' levels; Color 10YR8/2

yellow-green clay with a pseudo-porphyritic texture; texture is suggested by massive yellow-green matrix with white clay "phenocrysts".

90-003 quartz and clay; thin lens (3 $\mathrm{cm}$ thick) of gray-green clay within porous aggregate of quartz crystals; south wall between 480' and 500' levels; Color 5Y4/1

friable, very fine-grained, dark green-gray quartzose(?) sand; most grains to fine to identify, may have abundant clay matrix.

90-004 vuggy quartz, collected near argillized igneous dike; south wall between 480' and $500^{\prime}$ levels; Color 5GY3/2

friable, porous aggregate of black fine-grained quartz crystals; crystals $0.5 \mathrm{~mm}$ long; thin $(<1 \mathrm{~mm})$ zones of white clay cross the sample; most quartz grains are pitted and etched.

90-006 argillized hornfels; south wall between 520' and 540' working levels (Missouri Mountain Shale?); Color 10YR8/6

white to yellow-brown chalky clay; yellow-brown color is the result of iron oxide stain; stain is locally concentrated in disseminated spots $<0.2 \mathrm{~mm}$ wide; a trace of disseminated quartz crystals.

90-007 argillized hornfels; collected from a fracture zone; south wall between $520^{\prime}$ and $540^{\circ}$ working levels;; Color 5GY8/2

argillized hornfels; light-brown to green clay with small grains of dark-gray to black quartz and small cubes of pyrite; sample is soft and crossed by thin $<1 \mathrm{~mm}$ thick veinlets of yellow-green waxy clay.

90-008 hornfels; underlain by black novaculite/chert?; collected from north wall between $500^{\prime}$ and 520' level; Color 5GY6/1

slightly argillized medium bedded light to dark gray hornfels; dark gray beds are massive and siliceous; pyrite is disseminated along siliceous and clay veinlets; nodules as large as $1 \mathrm{~cm}$ of fine-grained pyrite are concentrated in the siliceous beds. 


\section{Appendix 1. Sample descriptions--Continued}

SAMPLE DESCRIPTON

90-009 argillized hornfels; northeast wall between 500' and 520' levels; Color N8 pyritic gray to light green clay coating small gray siliceous fragments; these fragments are crossed by thin $<1 \mathrm{~mm}$ dark glassy quartz veinlets; a few small pyritic zones

90-010 gossan; zone 10' wide of massive brown iron oxide intermixed with silica?; outcrop has irregular rounded fractures, bulges and pillows; east wall between 500' and 520' levels; Color 10YR5/6

massive gossan, dark brown with irregular fractures; unlike other gossans, iron oxides are massive; minor local coating of pink clay

90-011 argillized hornfels; south wall between 520' and 540' levels (Missouri Mountain Shale?); Color 10YR8/3

massive white chalky silty clay(?); light yellow-brown stain on some fracture surfaces;

90-012 argillaceous gossan; from fracture in road outcrop 500' east of Magnet Cemetery; Color 10YR8/4

brecciated gossan(?); friable light red, clay matrix; quartz, clay, and white novaculite clasts

90-014 argillized igneous dike fragment, east wall between 480' and 500' levels; Color $5 \mathrm{YR} 9 / 2$

argillized brecciated igneous dike fragments? surrounded by porous black recrystallized novaculite; clay is massive with light pink to red stain from iron oxides; disseminated purple grains of iron oxide have a width of 0.1 to $1 \mathrm{~mm}$

90-015 vuggy quartz; recrystallized novaculite near 90-014; collected from east wall between the 480' and 500' levels; Color $5 Y 7 / 1$

light brown-gray granular quartzite; grains are 0.1 to $2 \mathrm{~mm}$ and are coated with a white clay(?) that is sightly iridescent (taeniolite?)

90-016 siliceous gossan; collected from floor of the 480' level; Color 5YR5/4 fractured massive glassy quartz coated with dark brown massive iron oxides; some surfaces are coated with botryoidal orange-yellow iron oxides; quartz is black and cut by thin clear siliceous veinlets. 

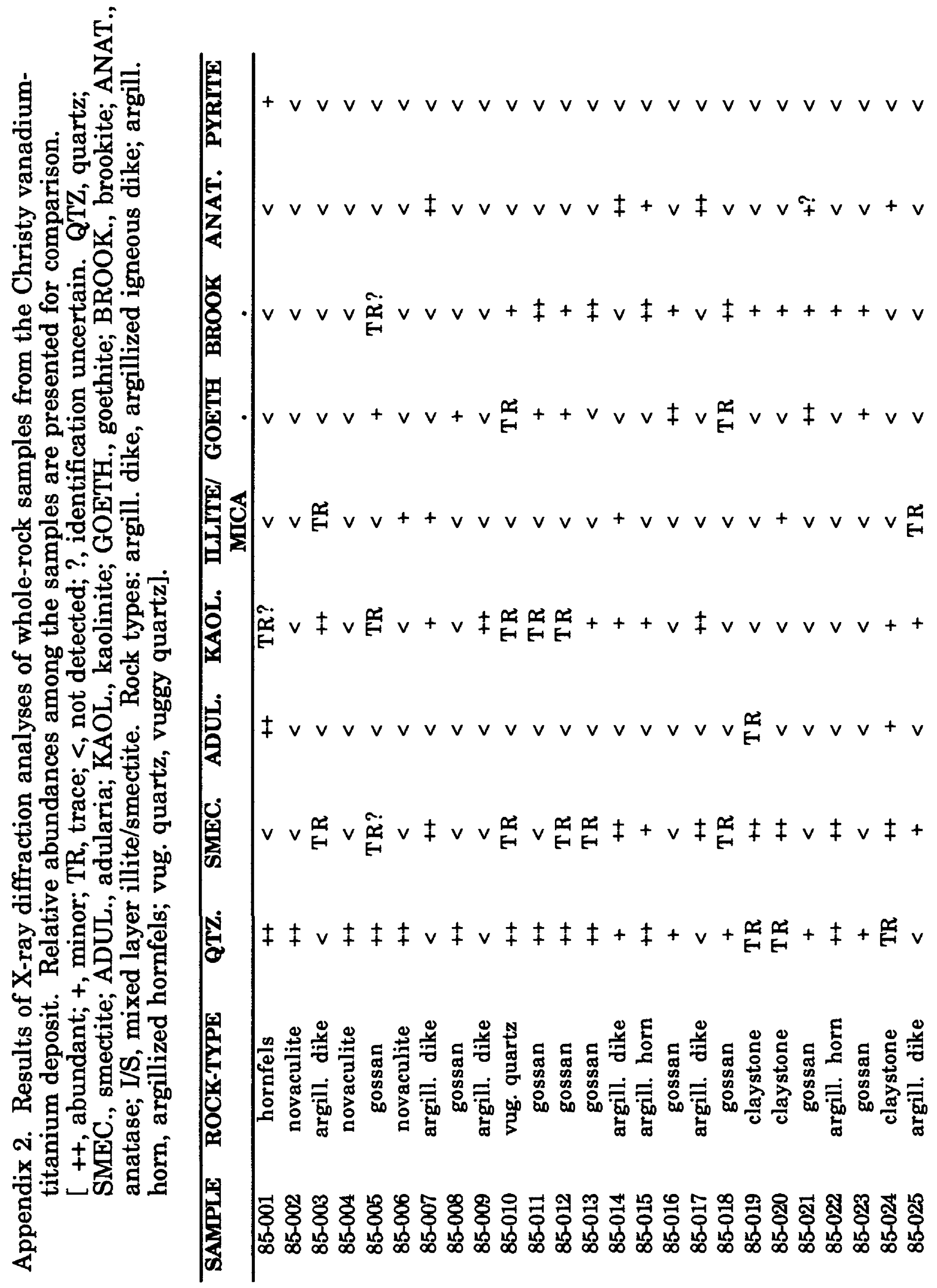


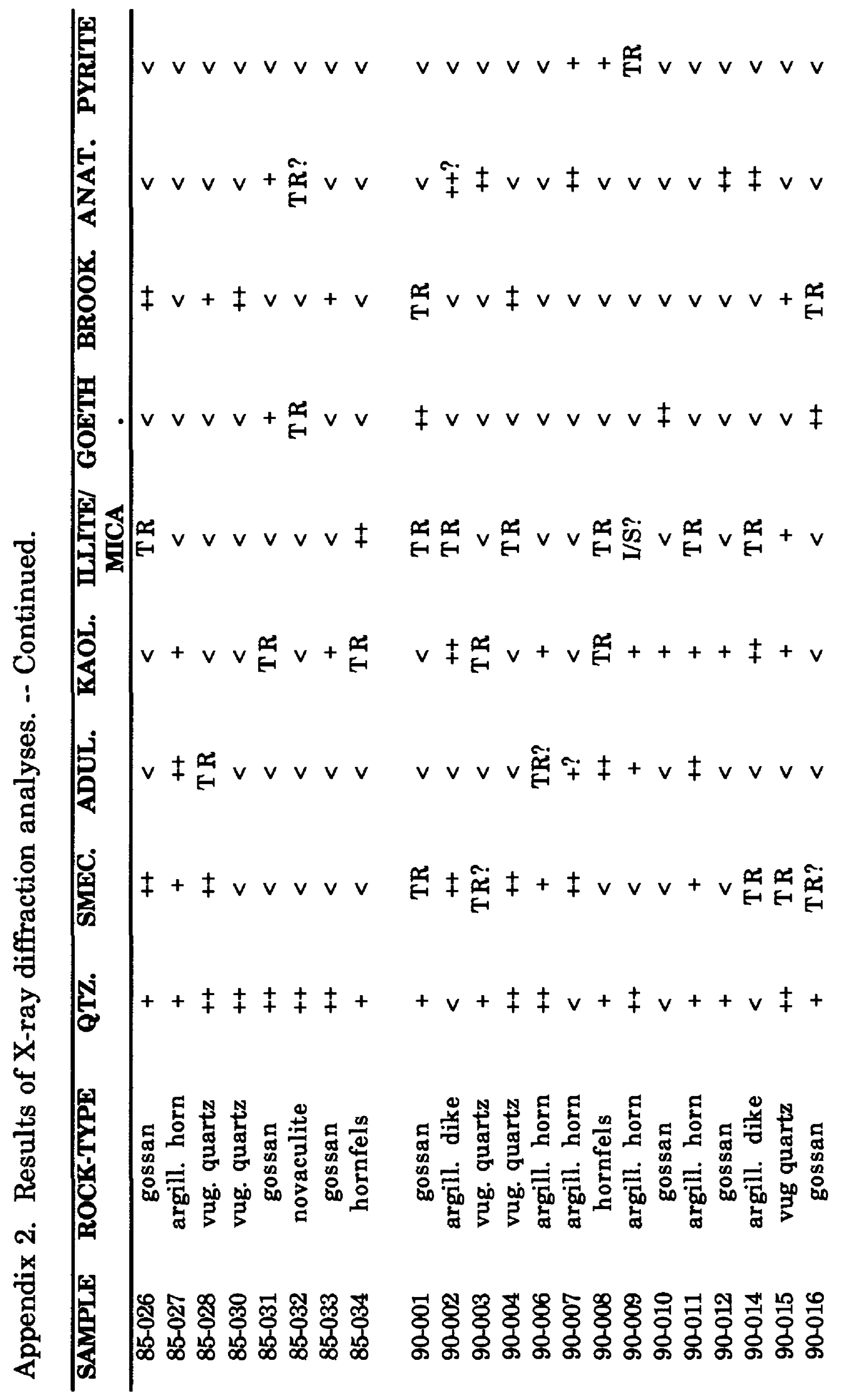




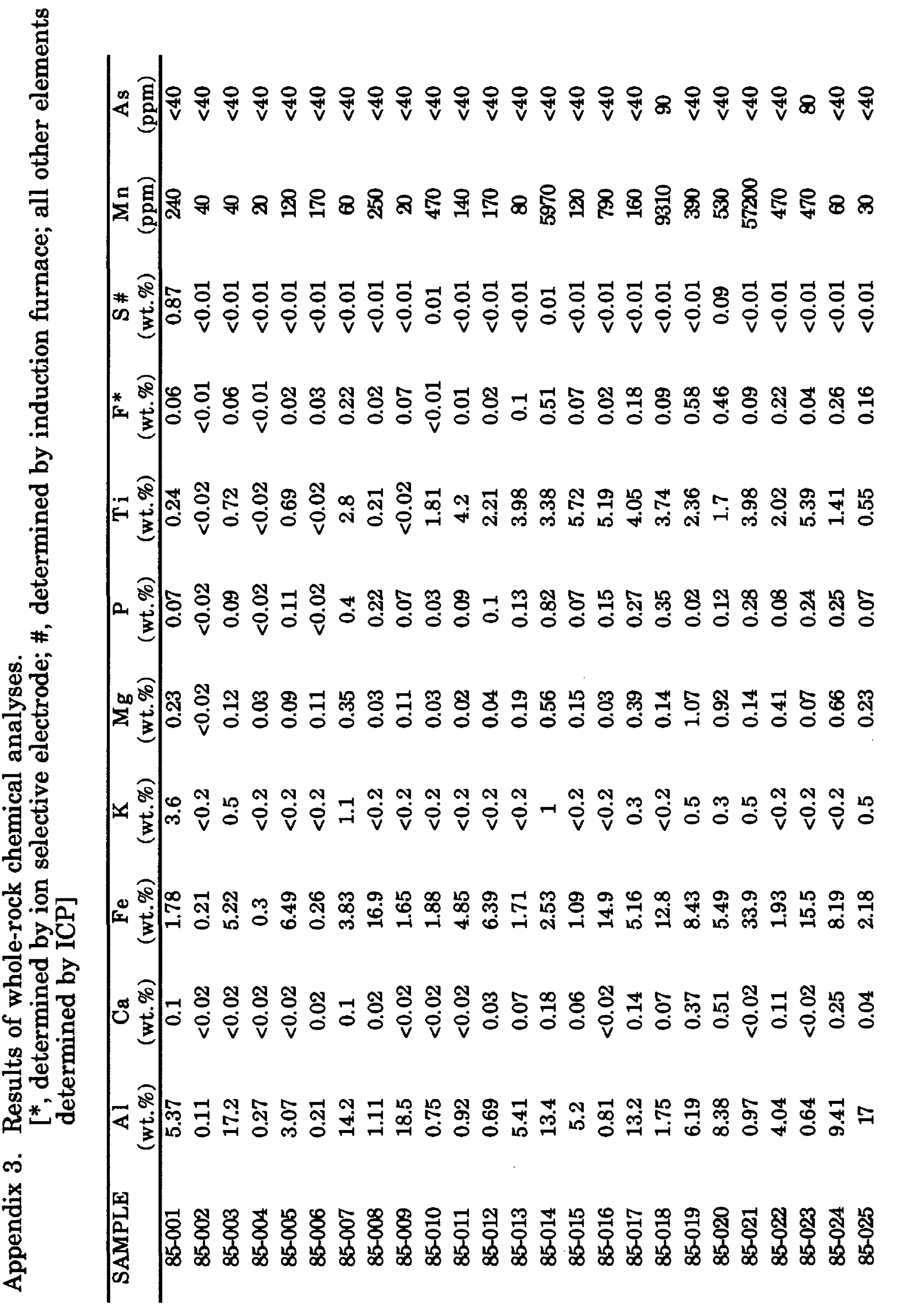




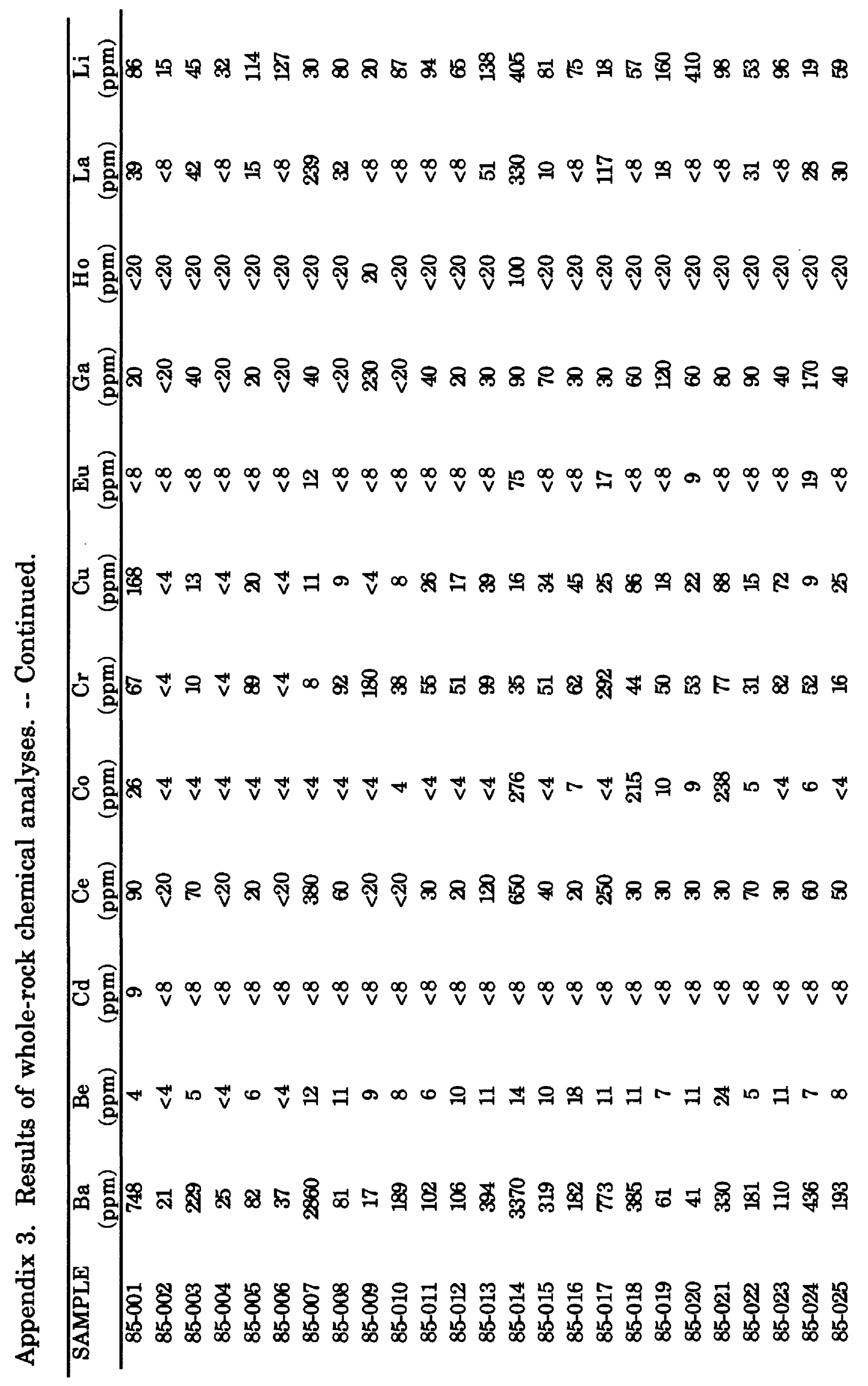




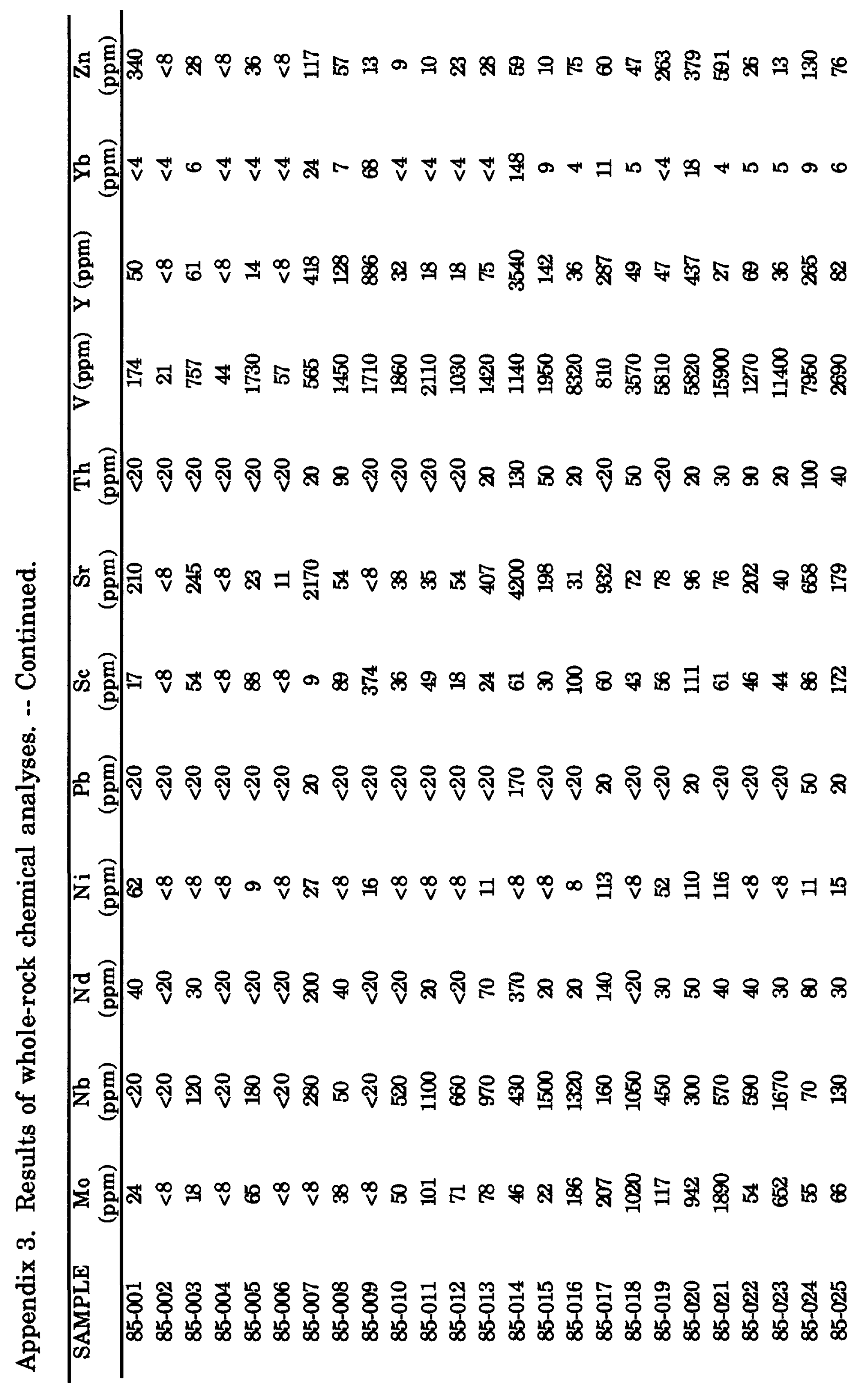




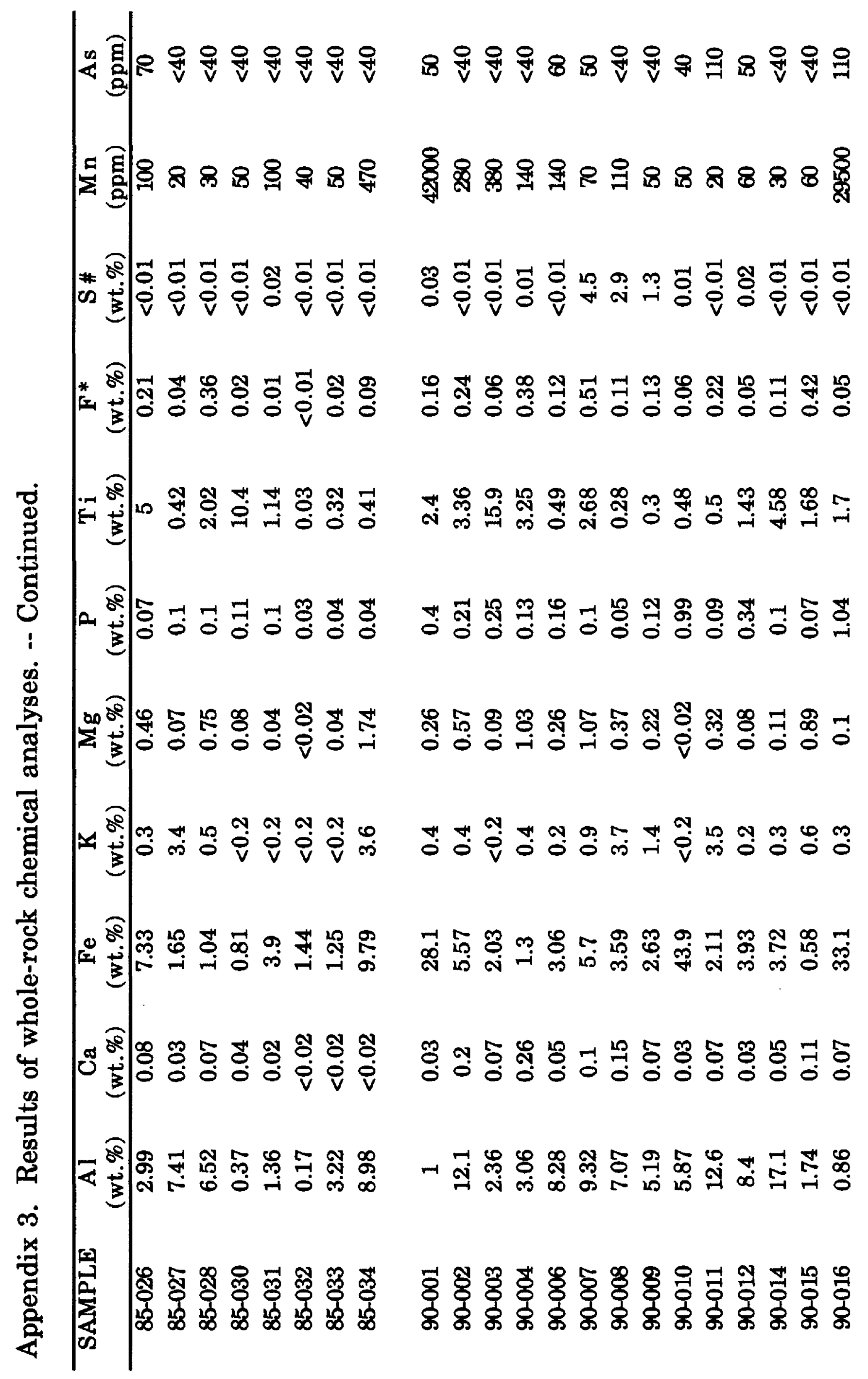


|ت

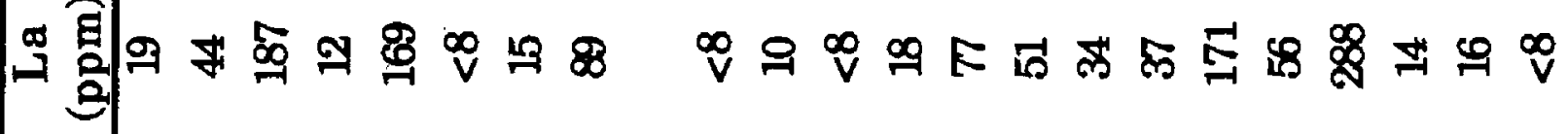

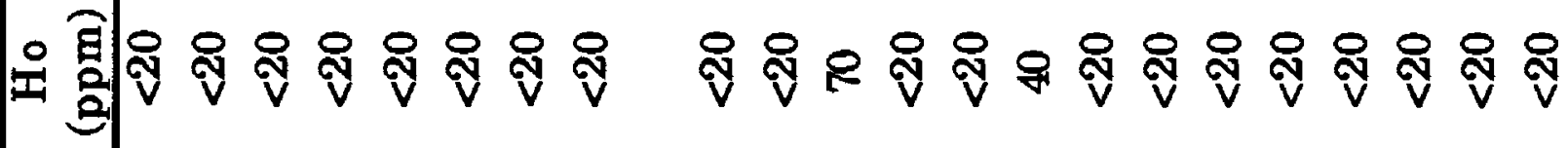

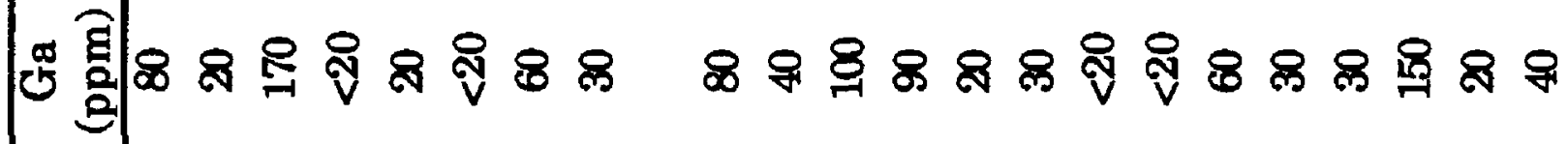

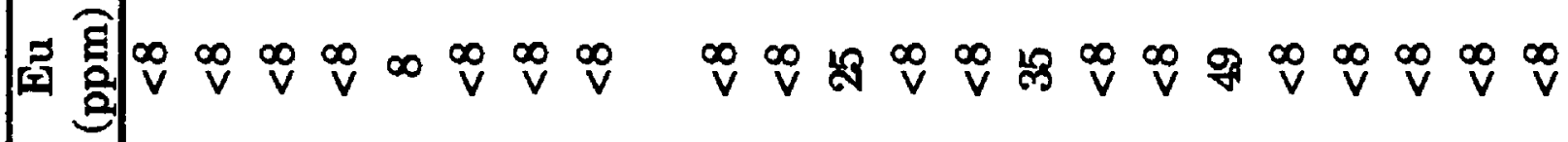

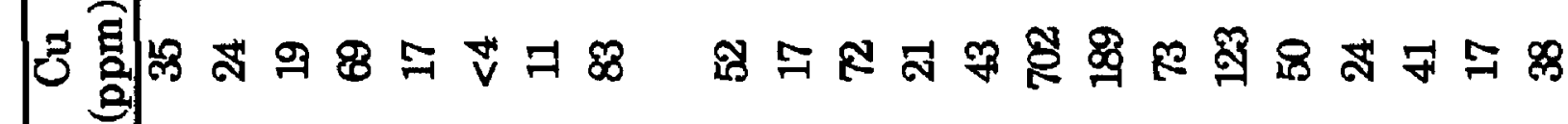

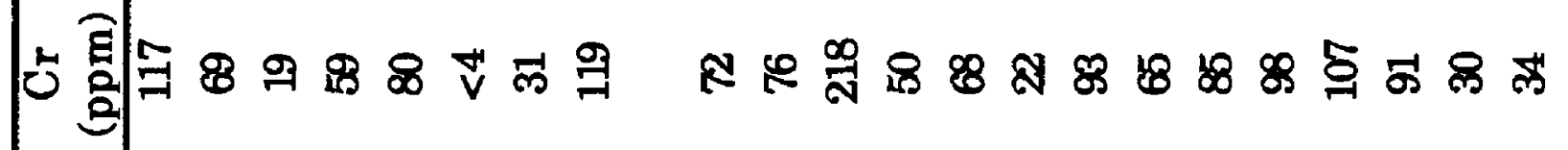
离

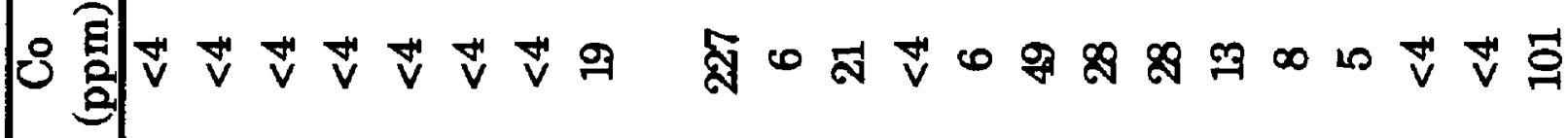

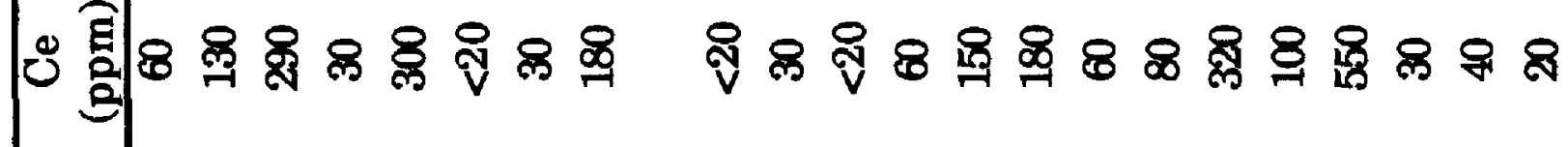
$\Rightarrow 0$ $\frac{0}{3}$ 4

䕇

๓

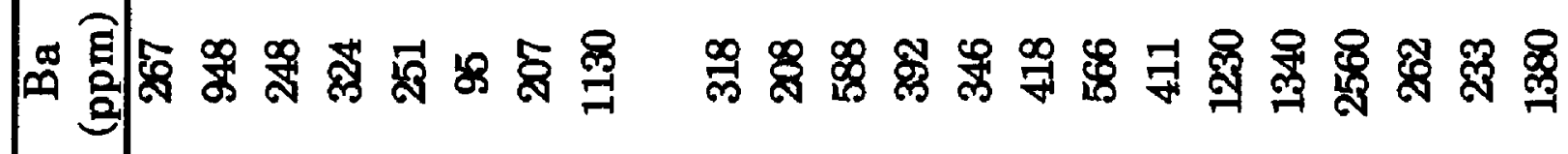
is $\because$ 我 产

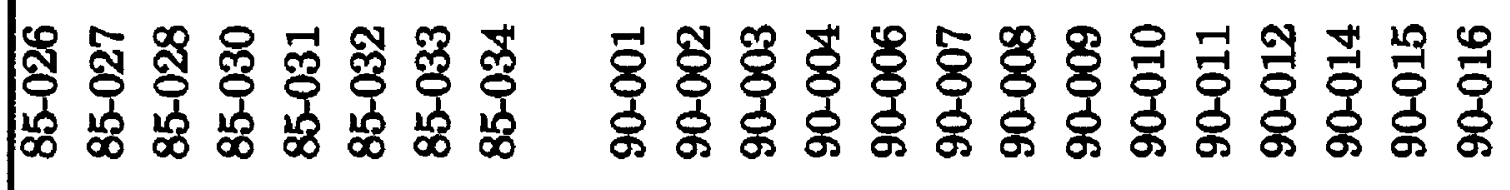

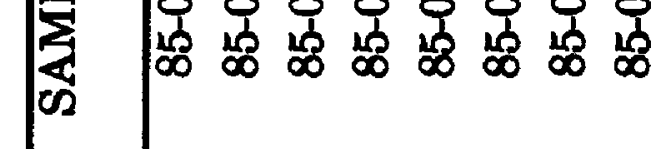




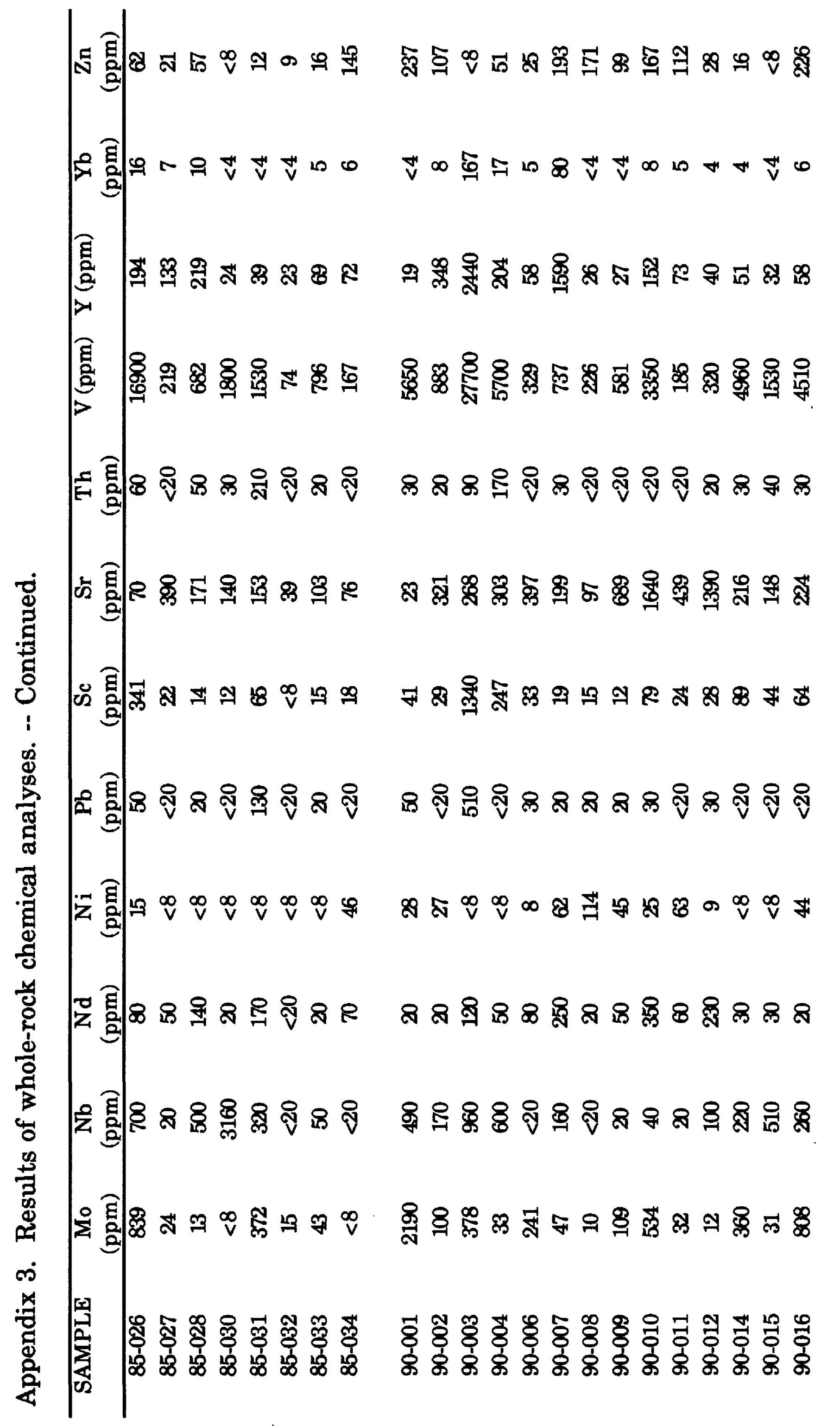

